\title{
THE VALIDITY OF WORLD CLASS BUSINESS CRITERIA ACROSS DEVELOPED AND DEVELOPING COUNTRIES
}

Authors:

Andre J. Parker ${ }^{1}$

Theo H. Veldsman ${ }^{1}$

\section{Affiliations:}

1Department of Industrial

Psychology and People

Management, University of

Johannesburg, South Africa

\section{Correspondence to:}

Theo Veldsman

email:

theov@uj.ac.za

Postal address:

Department of Industrial

Psychology and People

Management, University of

Johannesburg, PO Box 524,

Auckland Park 2006, South

Africa

\section{Keywords:}

Business; developed

countries; developing countries; world class criteria; world class practices

\section{Dates:}

Received: 15 Sept. 2009

Accepted: 29 Apr. 2010

Published: 11 Nov. 2010

How to cite this article: Parker, A.J., \& Veldsman, T.H. (2010). The validity of world class business criteria across developed and developing countries. $S A$ Journal of Human Resource Management/SA Tydskrif vir Menslikehulpbronbestuur, 8(1), Art. \#255, 17 pages. DOI: 10.4102/sajhrm.v8i1.255

\section{This article is available} at:

http://www.sajhrm.co.za
(C) 2010. The Authors.

Licensee: OpenJournals Publishing. This work is licensed under the Creative Commons Attribution License.

\begin{abstract}
Orientation: World class implies being able to respond effectively to the prevailing business challenges in a manner that surpasses competitors and to compete effectively in the global economy.
\end{abstract}

Research purpose: To assess the validity of the general assumption in the literature that world class criteria are equally applicable worldwide.

Motivation for research: The possibility exists that developing countries require an adjusted mix of world class criteria and practices to become globally competitive.

Research design, approach and method: A quantitative field survey research approach was adopted. A web-enabled questionnaire was designed, covering 35 world class practices grouped under 7 world class criteria. A cross-section of the senior management from 14 developing and 20 developed country's organisations partook in the study.

Main findings: It was empirically confirmed that the majority of world class practices posited in the literature are used by participating organisations; that world class criteria do not apply equally across developed and developing countries; and that more important than country location, is the deliberate choice by an organisation's leadership to become world class. An empirically based model of ascending to world class was proposed.

Practical/managerial implications: Regardless of country location, the leadership of an organisation can make their organisation world class by applying the proposed world class model.

Contribution/value add: A reliable web enabled instrument was designed that can be used to assess an organisation's world class standing; the assumption that world class criteria are equally valid across developing and developed countries was proven partially incorrect; since becoming or being world class is also a leadership choice regardless of location.

\section{INTRODUCTION}

Becoming world class implies becoming and being competitive with other similar businesses in the global arena. It means being able to respond effectively to prevailing business challenges in a manner that surpasses that of competitors, and to compete effectively in the global economy (De Kock \& Slabbert, 2003; Drennan \& Pennington, 1999; Nel, 1994). Inherent in studies of world class businesses is the assumption that the criteria which typify world class organisations are universal around the world without any distinction being made between developed and developing countries. This assumption implies that if these criteria were to be adopted in the same way anywhere in the world then an organisation would become world class. Yet the pursuit of becoming world class has not been universal or consistently successful across the globe.

Developed countries show a modern infrastructure (both physical and institutional) and a move away from low-value-added sectors such as agriculture and natural resource extraction to more intellectual and capital based economic activities. Developing countries in the context of this study have relatively low standards of living, undeveloped industrial bases and moderate to low human development indices (HDI) scores. Developing countries experience low per capita income, widespread poverty and low capital formation. They are, in general, countries that have not achieved a significant degree of industrialisation relative to their populations, which have a low standard of living. There is also a strong correlation between low income and high population growth in developing countries. By comparison developed countries have economic systems based on continuous, self-sustaining economic growth in their tertiary and quarternary sectors and high standards of living (Budwar \& Debrah, 2001).

Freely acknowledging that notable differences between cultures (and by implication countries) do exist, Collins and Porras (2002) encourage future research into the question of across country differences. The fact that globalisation creates compelling pressure to cross-integrate world class criteria, as well as the fact that contextual factors may be impacting across different cultures on the viability and effectiveness of ascendency to world class, is being acknowledged and questioned in what appears to be only confined circles (Budwar \& Debrah, 2001).

\section{OBJECTIVES OF STUDY}

The assumption that world class criteria are the same the world over, irrespective of developed or developing country status, ignores the possibility that developing countries require an adjusted formula of criteria and practices to become globally competitive. This research was intended to 
assess the validity of world class criteria across developed and developing countries.

More specifically, the objectives of the study were to provide answers to the following two questions, namely (1) do world class criteria, which lead in outstanding organisational performance in developed countries, differ from the criteria applicable to developing countries? and (2) what can organisations in developing countries learn from possible differences in criteria between developed and developing countries in order to embrace best practices that will work and be sustainable in their contexts?

The study aimed at closing the gap in knowledge of world class criteria or practices between developed and developing countries and to provide developing country organisations with a proposed model of world class together with recommended areas to ascend to world class.

\section{TRENDS FROM THE RESEARCH LITERATURE}

\section{World class business criteria and practices}

A review of the literature reveals commonly effective practices that can be grouped into a number of world class criteria, all of which are ascribed to world class organisations. For the purposes of this research, 'activities' are what an organisation does, whilst 'practices' are how the organisation does it. Criteria in this context means a set of common practices related to a world class theme, for example ongoing stretch and futuredriven strategising.

A review of the literature reported here revealed the following world class business criteria and practices, which can be grouped under seven criteria:

1. Ongoing stretch and future-driven strategising.

2. Transformational, distributed leadership.

3. All-round ownership and partnering amongst all stakeholders.

4. Customer-centric, process-based, teaming architecture.

5. Continuous improvement and relentless innovation.

6. An enabling and empowering people philosophy and practices.

7. Powerful internal and external branding to build and support a strong organisational identity.

Each of these criteria with their commensurate criteria is discussed next.

\section{Criterion 1: Ongoing stretch and future-driven strategising}

World class organisations in a global economy continually strive to meet customer needs and expectations. These businesses create and live innovative stretch strategies which aspire to recreate the future as a way of life (Collins \& Porras, 2002; Joyce, 2005; Nel \& Beudeker, 2009). Continual future creation and improvement renders conventional, linearly extrapolated strategic plans prematurely obsolete. Strategising in world class organisations becomes an organic, continual process to stay ahead of ever-moving goal posts and beacons, which is expressed in the strategic intent for the organisation in contrast to the conventional strategic plans (Beer, 2009; Browne, 2003; Hamel \& Prahalad, 1989; Hamel \& Prahalad, 1994; Tichy, 2002; Veldsman, 2002). This desire for progress lies deeply rooted in the organization's core ideology, which works hand in hand with its envisioned future (Veldsman, 2002).

Leading companies have strategies 'that focus the organisation on a clear, engaging set of shared goals' which means that strategy is '... shared and meaningful to those within the company' (Joyce, 2005, pp. 120-121, italics original). As the accompanying authors support, everyone partners in continually improving processes as guided by a close alignment of strategic thinking with all of the other interdependent practices and systems in the organisation (Collins, 2001; Simon, 2000; Telleria, Little \& MacBryde, 2002). The drive is for the best synergistic alignment of overarching and interdependent strategies to create balance and harmony that would eliminate waste and would drive high performance (Collins \& Porras, 2002; O’Reilly \& Pfeffer, 2000).

\section{Criterion 2: Transformational, distributed leadership}

Organisations in the 21st century global village are under pressure to continuously transform themselves. Those who fail to make the changes do not stay around to tell their tale (Stewart, 2006). This 'ability to adapt - and quickly' is brought about by transformational leaders instead of ordinary transactional leaders and even less by traditional managers (Simon, 2000, p. 217, italics original). World class organisations place an emphasis on and encourage, transformational leadership which is well spread across all organisational levels. Conventional organisations suffer from lack of leadership as a result of an undue emphasis on management (Collins, 2001; Joyce, 2005; Kotter, cited in Pfau \& Kay, 2002; Krames, 2005).

Transformational leadership is about bringing the new into being and transforming what exists into something new. 'Without transformational leadership, business organisations aspiring to attain world class are trying to "fire a canon from a canoe" (De Kock \& Slabbert, 2003, p. 6, italics original).

\section{Criterion 3: All-round ownership and partnering amongst all stakeholders}

Sharing of the organisation's long term plans with people and their extensive involvement go hand in hand (Flannery, Hofrichter \& Platten, 1996; Veldsman, 2002). Care is therefore taken in world class organisations to ensure that employees are treated as an integral part of the business with the intention to identify, realise and apply their full potential (Krames, 2005).

People partnering creates co-responsibility for success where everyone is mobilised around a commonly understood and internalised strategic intent (Beer, 2009; O'Reilly \& Pfeffer, 2000; Slater, 1999; Veldsman, 2002). Line management takes ownership of managing relationships with their people which imply incorporating people management into line. Under these conditions human resources professionals become strategic business partners as opposed to being merely a dedicated support function (Beatty \& Schneier, 1997).

This partnering approach also transcends the traditional boundaries of the organisation into networking and partnering with suppliers and customers (Beer, 2009; Nel \& Beudeker, 2009; Simon, 2000). Ongoing innovation occurs as a result of continued, joint problem solving with external stakeholders to the point of becoming a case of '... managing an ecosystem of relationships' (Stewart, 2006, p. 15, italics original). Common ownership of the strategic intent and continually evolving strategies are essential seeds for ensuring high performance and competitiveness (Nel, cited in Slabbert, Prinsloo, Swanepoel \& Backer, 1998). Dedicated business partnering with customers, where happy people partner with happy customers, builds relationships in which customers are seen as an extension of the culture (De Toni \& Tonchia, 1996; Grulke \& Sibler, 2002; Thorne \& Smith, 2000; Van Dyk \& Heroldt, 2003)

\section{Criterion 4: Customer-centric, process-based, teaming architecture}

Driven by transformational, distributed leadership, the organisation architecture (or design) starts with the customer as an outside perspective. Using the customer's opinion as a point of reference, core business processes are arranged in such a way so as to seamlessly transcend functional and organisation boundaries to deliver 'one stop' moments of truth to customers (Boxall \& Macky, 2009; Joyce, 2005; Nel \& Beudeker, 2009; 
Zairi, 1994). Efforts to build critical competencies around these integrated core business processes, the use of teaming, continuous learning and ongoing improvement inform a customer-centric architecture. Process improvements, often resulting from co-development with customers as partners, drive changes in the organisation architecture in order to maintain a customer-responsive value chain where every employee understands the bigger picture from a customer perspective (De Toni \& Tonchia, 1994; Hunt, 2000; Jones, 1994; Simon, 2000; Thorne \& Smith, 2000).

Cross functional teams find natural homes in world class organisations where core business processes are designed in such a way that decisions are made at the point of service delivery to the customer. This encourages 'boundaryless' behaviour which, in turn, gives people a greater sense of involvement in and ownership across the organisation. (Magee, 2003; Peters, 2003). All of the above is supported and enabled by an uncompromising technical excellence that ensures competitive advantage and market leadership in a context in which customers make the rules (Calloway, 2003; Thorne \& Smith, 2000).

\section{Criterion 5: Continuous improvement and relentless innovation}

Fueled by ongoing stretch and future-driven strategising, continuous improvement and relentless innovation form a way of life in world class organisations. This delights customers and in some instances may even transform an industry. Innovation becomes an essential part of the core ideology of the organisation (Joyce, 2005; Collins \& Porras, 2002) which translates into customer-driven innovations ahead of competitors and the market. Suppliers as strategic alliance partners are integrated into the business processes impacted on by continuous improvement and innovation and in this way are closely aligned to customer needs (Japanese Standards Association, 2003; Simon, 2000; Thorne \& Smith, 2000).

In the search for continued improvement, world class organisations benchmark their own levels of optimum performance against best-in-class in comparable businesses (Zairi, 1992). Although benchmarking in itself cannot be hailed as a panacea to attain world class performance, the process correctly applied enables world class organisations to reference and adjust their beacons by continuously raising the bar.

\section{Criterion 6: Enabling and empowering people philosophy and practices}

The strategic intent in world class organisations draws them forward. An critical enabler in this future recreation drive is the alignment of people management to the chosen strategic intent in order to build proactively overall sustainable people capacity ahead of demand (Nel \& Beudeker, 2009; Veldsman, 2002).

An increase in knowledge creation and the need for people to increase their skills repertoires have created the era of the knowledge worker (Veldsman, 2002). Continuous improvement and innovation are dependent on the rate of teaching and learning being faster than the rate of change, necessitating the creation of learning spaces for talent in the organisation and allowing them to move rapidly across boundaries as their careers unfold (Beer, 2009). In addition, an integrated view of performance exists which is measured in real time and focuses on inter-functional effectiveness which brings the core ideology and business strategy to life (Amaratunga \& Baldry, 2002). High participation partnerships, where goals are jointly established, create a sense of community which is performance-driven as opposed to goals being imposed on organisational members through coercion (Beer, 2009).

Reward as the outcome of performance management is seen as a holistic concept which is far wider than pay and requires a delicate, synergistic balance between extrinsic and intrinsic rewards. It drives continuous learning, develops a sense of ownership and encourages innovation and risk-taking. To achieve this, the components of performance and rewards are seamlessly integrated, seen as interdependent and systemic, and dealt with in real time and on-line (Gross \& Nalbatian, 2002; Nel \& Beudeker, 2009; O’Neal, 1998; Veldsman, 2002).

\section{Criterion 7: Powerful internal and external branding to build and support a strong organisational identity}

Branding pertains to what world class organisations stand for and what they promise to their customers. Their brand promise resides in the hearts and minds of their customers and all their stakeholders (Calloway, 2003; Swart, 2005). The sum total of vision, values and culture in the form of a strong brand proposition is more compelling than its individual components. One of the cornerstones of a strong partnership is ascribed to a compelling brand.

When someone asks any of our employees who they work for, we want them to be able to say 'e-bank' with pride and convictioneven in a pub. We want to build a business that we are proud of. We want our family and friends to know we work for the best on line bank in the world - the best because our customers say so

(Grulke \& Sibler, 2002, p. 99)

The question as to whether these interwoven world class criteria are equally applicable in developed and developing countries remains unanswered at the end of the literature review, because researchers do not address the issue. It is readily assumed in the literature reviewed that the seven criteria discussed apply equally irrespective of country context. The core issue that still remains at the end of the review is the contextual validity of world class criteria across developed and developing countries. Are these criteria equally applicable across these two types of countries? This is what the research reported here sets out to investigate.

\section{RESEARCH DESIGN}

\section{Research approach}

The source and nature of the data to be collected called for a quantitative field survey research approach to gather primary data. This decision was based on the pragmatic need of the study having to reach a variety of organisations in different countries around the world and not on any particular personal belief in, or bias by, the researchers towards a particular research approach.

\section{Research variables}

The independent, dependent and moderating variables of the study and their inter-relationships are presented in Figure 1.

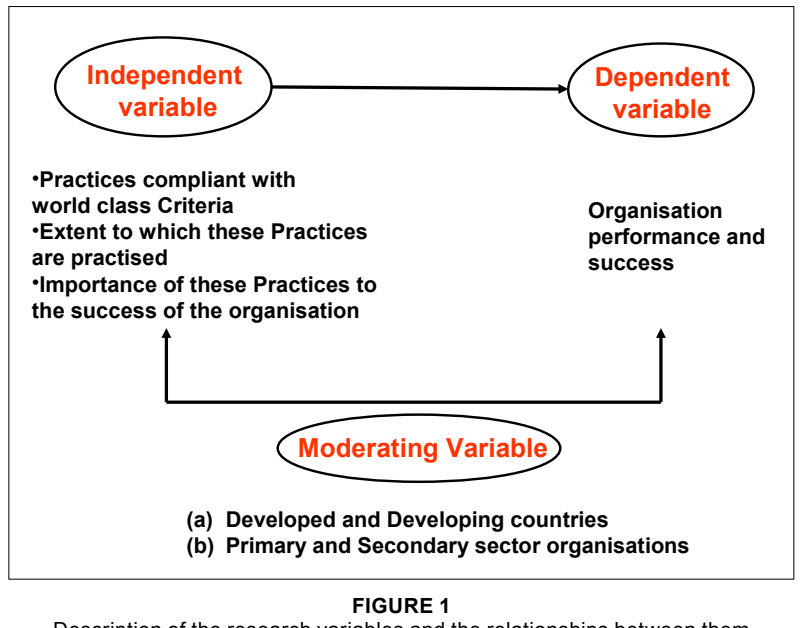

Description of the research variables and the relationships between them 
A limitation of the study was that no common measurement of the dependent variable as given in Figure 1 could be obtained across the globally participating organisations. The independent and moderating variables, however, could be measured.

\section{Propositions tested}

In weighing up whether the research was dealing with 'research hypotheses' or 'propositions', it was concluded that the study was investigating propositions and not hypotheses since a theory of world class criteria and practices across developed and developing countries has not been explicitly formulated. Propositions were therefore formulated to operationalise the world class criteria discussed in the above literature review. These propositions were used to test the validity of world class criteria across developed and developing countries.

The propositions to be tested were as follows:

\section{Criterion 1: Ongoing stretch and future-driven strategising}

Proposition: World-class organisations create and live innovative transformational strategies with a continual stretch and future creation mind-set as a way of life.

\section{Criterion 2: Transformational, distributed leadership}

Proposition: Transformational leadership in world class organisations is about bringing the new into being and/or transforming what exists into something new. It is about being continually discontent, relentlessly pursuing possible desirable futures whilst mobilising followers towards an envisioned future.

\section{Criterion 3: All-round ownership and partnering} amongst all stakeholders

Proposition: Ownership and partnering in world class organisations extends across both internal and external functional boundaries where an action community of stakeholders is mobilised around seamless business processes to deliver on peak-to-peak levels of customer service.

Criterion 4: Customer-centric, process-based, teaming organisation architecture

Proposition: World class organisations design their core business process to exceed their customer's expectations. Processes flow seamlessly across functional boundaries, end-to-end, and incorporate suppliers, key stakeholders and internal customers along the process value stream.

Criterion 5: Continuous improvement and relentless innovation

Proposition: The acceleration of continuous improvement coupled with quantum leaps in innovation is a way of life for world class organisations. Living this mind-set, continuous improvement and relentless innovation act as a source of energy.

\section{Criterion 6: An enabling and empowering people philosophy and practices}

Proposition: People practices in world class organisations are consistently aligned with one another and the organisation's core ideology.

\section{Criterion 7: Powerful internal and external branding} to build and support strong organisation identity

Proposition: Branding is who and what world class organisations stand for and what they promise to their customers. Their brand promise is lived by everyone and resides in the hearts and minds of their customers and all their stakeholders.

\section{Research method}

\section{Research participants}

Organisations in both developed and developing countries earmarked to participate in the study were recognised as operating at high performance levels in their respective countries. Whilst no common organisational success measurements could be applied, which was a limitation of the research, each of the participating companies had posted year-on-year growth on their web site reports. The sample was made up of 34 organisations, 14 from developing countries (South Africa, Namibia) and 20 from developed countries (Belgium, Canada, France, Germany, Ireland, Italy, Netherlands, the Russian Federation, Spain, Sweden, Switzerland, United Kingdom, USA).

While the study sought to research the validity of world class criteria between developed and developing countries, the only countries where responses could be obtained were in the southern African region. The findings of the study therefore are empirically more directly applicable to the southern African region than the rest of the developed countries around the world.

Participants within these organisations consisted of a crosssection of the top three to four senior management levels of participating organisations (427 questionnaires were completed out of 560 invitations to participate, a response rate of $76.3 \%$ ). The ratio of respondents at organisational level, the one unit of analysis, of developed to developing countries was $59 \%$ to $41 \%$. Organisations from the primary and secondary sector were closely balanced within developed and developing countries respectively. It was suspected that differences in practices could occur between primary and secondary sector organisations due to the former being mostly industrial orientated whilst the latter is more commercially orientated, living closer to the 'final' customer.

Participants came predominantly from the sales (18.3\%), finance $(11.0 \%)$ and manufacturing functions $(10.8 \%)$. Nearly $70 \%$ of the participants were in senior to executive management positions with close on $65 \%$ having more than 3 years experience in their current positions, $62 \%$ being with their present organisations for more than 6 years. Just short of $80 \%$ of participants had tertiary qualifications. The respondents were thus well informed and experienced to participate in this study.

\section{Measuring instrument}

A new web-enabled questionnaire was developed for the purpose of this study. The world class practice statements used in the questionnaire with respect to each world class criterion as derived from the propositions to be tested as well as their number and contents are given in Table 1 . Five practices were identified associated with each of the seven world class criteria.

Using a 5-point Likert scale, the instrument required respondents to first rate the 'extent to which a practice was being observed in their respective organisations' and then, secondly, to rate the 'relative importance of a practice to organisation success' by distributing 100 points over the practices. The last screen of the survey required respondents to rate the overall relative importance of all seven world class criteria by distributing 100 points across the seven criteria. Respondents were also required to provide biographical information about themselves.

\section{Research procedure}

Given the geographic expanse and complexities to survey world class organisations over developed and developing countries, the simplicity and effectiveness of an e-questionnaire and e-data-capturing on a dedicated server was used to provide guarantees of data completeness and integrity. The e-based process ensured that a respondent could not move to a next screen unless all the responses were completed and that rating scales added up to 100 . 
TABLE 1

Practice statements used in the questionnaire in respect of each world class criterion

\begin{tabular}{|c|c|c|c|c|}
\hline & Questionnaire & In our organisation ... \\
\hline \multirow{7}{*}{ 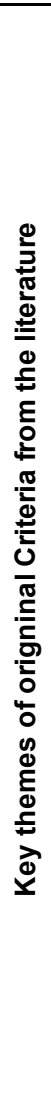 } & ¿্ঠ & 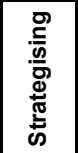 & $\begin{array}{l}1.1 \\
1.2 \\
1.3 \\
1.4 \\
1.5\end{array}$ & $\begin{array}{l}\text { strategising is about creating a desired future } \\
\text { strategising is an ongoing process throughout the year } \\
\text { strategies rapidly change to meet changing customer needs } \\
\text { strategies are shared and owned by everyone } \\
\text { strategies stretch us beyond what we believe is currently possible }\end{array}$ \\
\hline & 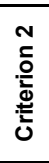 & $\frac{\frac{0}{\bar{N}}}{\frac{1}{0}}$ & $\begin{array}{l}2.1 \\
2.1 \\
2.3 \\
2.4 \\
2.5\end{array}$ & $\begin{array}{l}\text { leadership drives continual change } \\
\text { leadership focuses on creating something new } \\
\text { leadership 'thinks out of the box' } \\
\text { leadership ensures that everyone shares the same future } \\
\text { everone is expected to show leadership }\end{array}$ \\
\hline & 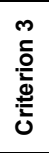 & 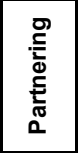 & $\begin{array}{l}3.1 \\
3.2 \\
3.3 \\
3.4 \\
3.5\end{array}$ & $\begin{array}{l}\text { all our stakeholders partner with us in our business } \\
\text { our people build close relationships with our customers } \\
\text { people are seen as key to the success of our business } \\
\text { we both compete and collaborate with our competitors } \\
\text { partnering with our stakeholders drives continuous improvement and innovation for everyone }\end{array}$ \\
\hline & 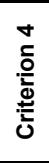 & 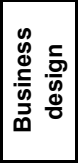 & $\begin{array}{l}4.1 \\
4.2 \\
4.3 \\
4.4 \\
4.5\end{array}$ & $\begin{array}{l}\text { we think like our customers } \\
\text { customer needs and expectations determine how we design our business processes } \\
\text { our business processes are closely interconnected to serve our customers seamlessly } \\
\text { core capabilities that enable business processes are are built through ongoing learning } \\
\text { teams are designed around business processes }\end{array}$ \\
\hline & 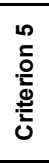 & 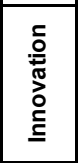 & $\begin{array}{l}5.1 \\
5.2 \\
5.3 \\
5.4 \\
5.5\end{array}$ & $\begin{array}{l}\text { good is never good enough } \\
\text { competitive standards are achieved through benchmarking against other organisations } \\
\text { innovative ideas are born by working close to customers and suppliers } \\
\text { an inner urge for continous improvement flows from what the organisation stands for } \\
\text { leaps in innovation is the norm rather than the exception }\end{array}$ \\
\hline & 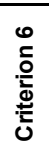 & $\frac{0}{\circ}$ & $\begin{array}{l}6.1 \\
6.2 \\
6.3 \\
6.4 \\
6.5\end{array}$ & $\begin{array}{l}\text { people development is driven by the organisation's desired future } \\
\text { teaching and learning takes place ahead of change } \\
\text { people are multi-skilled and multi-tasked to enable their flexible deployment across the organisation } \\
\text { real time performance feedback is ongoing with readily accessible performance information } \\
\text { performance, reward and recognition are closely linked }\end{array}$ \\
\hline & 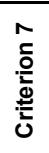 & 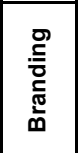 & $\begin{array}{l}7.1 \\
7.2 \\
7.3 \\
7.4 \\
7.5\end{array}$ & $\begin{array}{l}\text { our brand and what we stand for is understood by everyone in the organisation } \\
\text { our brand is lived by everyone in our organisation in our day to day operations } \\
\text { our brand is who and what we are, and what we stand for in the hearts and minds of our customers } \\
\text { our brand is experienced the same way by all our stakeholders, internal and external to the organisation } \\
\text { our brand delivers what it promises to our customers }\end{array}$ \\
\hline
\end{tabular}

Respondents were able to log onto the world class research web site anywhere in the world at any time, allowing data to be captured in real time. The rate of response was constantly monitored. The first two screens of the survey instrument captured essential individual and organisation biographical data.

An independent survey technology company was contracted for the conversion of the questionnaire for on-line web-based application, the hosting, the monitoring of response rates and the capturing of the data. Respondents were nominees from participating organisations whose email addresses were forwarded to the researcher. Each respondent received an e-mail containing the log-on website and a user password to access the survey. Ethical considerations took into account the opinion that participants would not be comfortable to have their particulars published.

\section{Data analysis}

The psychometric properties of the instrument: The factorial structure and reliability of the survey instrument were determined. Factors were extracted using Principal Axis factoring. A Varimax rotation with Kaiser normalisation was applied for the first-level factor analysis whilst an Oblimin rotation method with Kaiser normalisation was used for the second-level factor analysis. The recommended procedure suggested by Scheepers $(1992 ; 2004)$ to do both first and second level factor analyses was followed to reduce the probability of extracting artificial factors during the first order factor analysis. The number of factors extracted during the first and second level factor analyses was based on Kaiser's criterion of Eigenvalues larger than unity. For the reliability analyses, Cronbach's alpha coefficients were calculated on the extracted first- and second-order factors.
Two sets of factor and reliability analyses - one exploratory (the factors to be given by what is present in the data) and the other confirmatory (to see whether the factors built into the questionnaire as derived from the literature review were present in the data) - were conducted. This was followed by a visual, logical comparison of the degree of overlap of the factors extracted through the exploratory and confirmatory factor analyses respectively. The extracted factors were seen to represent the world class criteria.

Testing the propositions: To accept or reject the research propositions survey responses were grouped into two analysis categories, a first category using individual respondents as the unit of analysis and a second category using organisations as the unit of analysis. Each category was sub-divided in respect of primary versus secondary sector (or industry) organisations, as well as developing versus developed countries respectively. In the case of individuals as unit of analysis, $t$-tests were used to test for the acceptance or not of propositions.

In the case of the organisations as unit of analysis it was deemed necessary to combine the responses of all of the responses of participants of an organisation into a single response per practice. To ensure that respondents were applying the same frame of reference to the practices and to arrive at a stable summated response, interrater reliabilties were calculated for the participating companies $(N=32)$ with more than five respondents. Companies of interrater relaibilities of greater than 0.65 were included in testing the propositions. This resulted in 22 and 17 companies included for the exploratory and confirmatory criteria respectively. The Mann-Whitney $U$-test and Wilcoxon $W$-test were applied to test for statistical significance instead of a $t$-test because of the small sample sizes perhaps violating the assumption of a normal distribution. 
Statistical tests, as indicated above, were used to assess the extent to which means were statistically different on the factorially extracted world class criteria. Practical significance was arrived at by determining the effect size which is a measure of the strength of the relationship between two variables. The following effect categorisation was applied, $0.0-0.1$ (no practical effect), 0.1-0.3 (small effect), 0.3-0.5 (medium effect) and 0.5 -0.1 (large practical effect) (Rosenthal, Rosnow \& Rubin, 2000). A conservative decision rule position was selected to reject (or inversely accept) a proposition based on a combination of statistical significance and practical significance. A proposition was rejected if statistically significant with $p<0.05$ and practical significance of a small effect or greater, or if statistically insignificant with $p>0.05$ but with practical significance of medium effect or greater. A proposition was accepted if it was statistically insignificant with a $p>0.05$ and practical significance of no or small effect.

The above statistical tests were performed on organisations as per their given physical location in a developed or a developing country. Cluster analyses were conducted to determine statistically the appropriate grouping of the organisations surveyed. That is not to assume that world class equates to a physical location, namely developed or developing country. A hierarchical cluster analysis, using the ward clustering method was conducted, using both the exploratory and confirmatory world class criteria with organisations as unit of analysis. The resultant clusters were used categories as to test the acceptance or rejection of the propositions, again using the above described statistical tests.

\section{RESULTS}

\section{Questionnaire of the Psychometric properties}

On account of limited space the detailed statistical results of the factor and reliability analyses are not reported here, but are available upon request.
The first order exploratory factor analysis produced five reliable exploratory world class criteria and related practices which explained $46.9 \%$ of the total variance, which were entitled as follows, (1) innovative, learning based partnering, (2) powerful branding, (3) performance, reward-driven people, (4) customercentric, shared vision-driven leadership and (5) customercentric business design. Reliability coefficients for the first order, exploratory factors ranged between 0.74 and 0.87 . These were regarded as acceptable in the case of a newly constructed survey instrument.

The second order exploratory factor and reliability analysis constituted a single world class factor and hence, one world class theme (or criterion). An overall, acceptable reliability of 0.93 was attained across all 27 practices for this single factor. This single second order exploratory world class criterion was described as follows, brand-driven, transformational leadership where performance and reward driven people are continuously learning and improving business designs which are centered around their customers.

The confirmatory factor analysis sought to determine whether the extent to which the seven world class criteria and their related practices, as distilled from the literature review and built into the survey instrument, actually existed. The confirmatory factor analysis resulted in three world class criteria being removed from further statistical analysis since they did not meet minimum factorial requirements, for example Eigenvalues less than 1 and less than 3 items loading per theoretically-determined factor. The rejected criteria were, transformational, distributed leadership (criterion 2), all-round ownership and partnering amongst all stakeholders (criterion 3), and continuous improvement and relentless innovation (criterion 5). This left four confirmatory world class criteria for further analysis. The acceptable criteria were, ongoing stretch and future-driven strategising (criterion 1), customer-centric, process-based, teaming organisation architecture (criterion 4), an enabling and empowering people philosophy and practices (criterion 6) and powerful internal and external branding to

TABLE 2

Individual respondents as unit of analysis: developed versus developing countries

\begin{tabular}{|c|c|c|c|c|c|c|c|c|c|c|}
\hline \multirow{2}{*}{ Criterion } & \multirow{2}{*}{ Criterion description } & \multirow[t]{2}{*}{$\begin{array}{l}\text { Moderating } \\
\text { variables }\end{array}$} & \multicolumn{3}{|c|}{ Descriptive } & \multicolumn{3}{|c|}{ Statistical significance } & \multirow{2}{*}{$\begin{array}{l}\text { Effect size: } \\
\text { Practical } \\
\text { significance }\end{array}$} & \multirow{2}{*}{$\begin{array}{l}\text { Effect } \\
\text { size: } \\
\text { Coded }\end{array}$} \\
\hline & & & $N$ & Mean & s.d. & $\begin{array}{c}\text { Mann- } \\
\text { Whitney U }\end{array}$ & $\begin{array}{c}\text { Wilcoxon } \\
\text { W }\end{array}$ & $P$ Value & & \\
\hline Exploratory & $\begin{array}{l}1 \text { Innovative, learning based } \\
\text { partnering }\end{array}$ & $\begin{array}{l}\text { Developed } \\
\text { Developing }\end{array}$ & $\begin{array}{l}138 \\
286\end{array}$ & $\begin{array}{l}3.5321 \\
3.4620\end{array}$ & $\begin{array}{l}0.6400 \\
0.6504\end{array}$ & 1.045 & 422.000 & 0.297 & 0.051 & None \\
\hline Exploratory & 2 Powerful branding & $\begin{array}{l}\text { Developed } \\
\text { Developing }\end{array}$ & $\begin{array}{l}139 \\
286\end{array}$ & $\begin{array}{l}3.4921 \\
3.5049\end{array}$ & $\begin{array}{l}0.7679 \\
0.8653\end{array}$ & -0.148 & 423.000 & 0.882 & 0.007 & None \\
\hline Exploratory & $\begin{array}{l}3 \text { Performance and reward } \\
\text { driven people }\end{array}$ & $\begin{array}{l}\text { Developed } \\
\text { Developing }\end{array}$ & $\begin{array}{l}139 \\
286\end{array}$ & $\begin{array}{l}3.8010 \\
3.5385\end{array}$ & $\begin{array}{l}0.7809 \\
0.8944\end{array}$ & 2.955 & 423.000 & 0.003 & 0.142 & \\
\hline Exploratory & $\begin{array}{l}4 \text { Customer centric, shared } \\
\text { vision driven leadership }\end{array}$ & $\begin{array}{l}\text { Developed } \\
\text { Developing }\end{array}$ & $\begin{array}{l}139 \\
286\end{array}$ & $\begin{array}{l}3.7762 \\
3.6375\end{array}$ & $\begin{array}{l}0.5575 \\
0.7261\end{array}$ & 2.171 & 345.589 & 0.031 & 0.096 & None \\
\hline Exploratory & $\begin{array}{l}5 \text { Customer centric business } \\
\text { design }\end{array}$ & $\begin{array}{l}\text { Developed } \\
\text { Developing }\end{array}$ & $\begin{array}{l}139 \\
286\end{array}$ & $\begin{array}{l}3.6594 \\
3.5967\end{array}$ & $\begin{array}{l}0.8130 \\
0.8441\end{array}$ & 0.725 & 422.000 & 0.496 & 0.035 & None \\
\hline Exploratory & World class & $\begin{array}{l}\text { Developed } \\
\text { Developing }\end{array}$ & $\begin{array}{l}137 \\
286\end{array}$ & $\begin{array}{l}3.6534 \\
3.5519\end{array}$ & $\begin{array}{l}0.5460 \\
0.6259\end{array}$ & 1.625 & 421.000 & 0.105 & 0.079 & None \\
\hline Confirmatory & $\begin{array}{l}1 \text { Ongoing stretch and future- } \\
\text { driven strategising }\end{array}$ & $\begin{array}{l}\text { Developed } \\
\text { Developing }\end{array}$ & $\begin{array}{l}140 \\
286\end{array}$ & $\begin{array}{l}3.8171 \\
3.6483\end{array}$ & $\begin{array}{l}0.5923 \\
0.7651\end{array}$ & 2.503 & 346.166 & 0.013 & 0.111 & \\
\hline Confirmatory & $\begin{array}{l}\text { Customer-centric, process- } \\
4 \text { based, teaming organisation } \\
\text { architecture }\end{array}$ & $\begin{array}{l}\text { Developed } \\
\text { Developing }\end{array}$ & $\begin{array}{l}138 \\
286\end{array}$ & $\begin{array}{l}3.7043 \\
3.6196\end{array}$ & $\begin{array}{l}0.6921 \\
0.7090\end{array}$ & 1.162 & 422.000 & 0.246 & 0.056 & None \\
\hline Confirmatory & $\begin{array}{l}\text { An enabling and empowering } \\
6 \text { people philosophy and } \\
\text { Practice }\end{array}$ & $\begin{array}{l}\text { Developed } \\
\text { Developing }\end{array}$ & $\begin{array}{l}139 \\
286\end{array}$ & $\begin{array}{l}3.5367 \\
3.2455\end{array}$ & $\begin{array}{l}0.6581 \\
0.7998\end{array}$ & 3.981 & 325.941 & 0.000 & 0.178 & \\
\hline Confirmatory & $\begin{array}{l}\text { Powerful internal and } \\
\text { external branding to build } \\
\text { and support a strong } \\
\text { organisation identity }\end{array}$ & $\begin{array}{l}\text { Developed } \\
\text { Developing }\end{array}$ & $\begin{array}{l}139 \\
286\end{array}$ & $\begin{array}{l}3.4921 \\
3.5049\end{array}$ & $\begin{array}{l}0.7679 \\
0.8653\end{array}$ & -0.148 & 423.000 & 0.882 & 0.007 & None \\
\hline
\end{tabular}

s.d., standard deviation. 
build and support a strong organisation identity (criterion 7). An overall, acceptable reliability of 0.74 was attained across all of the practices as contained in the four factors.

Correspondence of the factors extracted respectively by the exploratory and confirmatory factor analyses was evaluated through visual inspection. Plotted on a matrix - the factors extracted by each type of factor analysis, namely exploratory and confirmatory, forming each a side of the matrix - the overall sum of corresponding practices between the confirmatory and exploratory criteria equated to a $76.6 \%$ overlap. In effect, it can be argued that the exploratory and confirmatory factor analyses produced what now constituted empirically determined world class criteria.

\section{Testing propositions}

The results of the statistical and effect testing of the propositions are reported respectively in terms of individuals and organisations as units of analysis, comparing developed versus developing countries followed by comparing primary and secondary sectors. The decision rule decided on above was applied in accepting or rejecting propositions.

\section{Individuals as unit of analysis}

The presence of a world class criterion in the organisation using individuals as unit of analysis: Comparing developed vs developing countries as well as primary vs secondary sectors results are depicted in Table 2 and 3.

According to Tables 2 and 3 the testing of the propositions using individuals as unit of analysis produced the following results:

Rejected propositions: World class criteria differed between countries and/or sectors:

- performance- and reward-driven people (exploratory criterion: developed countries higher than developing

countries, secondary sector higher than primary sector)

- ongoing stretch and future-driven strategising (confirmatory criterion: developed countries higher than developing countries)

- enabling and empowering people philosophy and practices (confirmatory criterion: developed countries higher than developing countries, secondary sector higher than primary sector).

The effect size that is the practical significance, in all cases was small.

Accepted propositions: World class criteria are the same across countries and/or sectors:

- ongoing stretch and future-driven strategising (confirmatory criterion: sectors similar)

- innovative, learning based partnering (exploratory criterion: countries and sectors are similar)

- powerful branding (exploratory or confirmatory criteria: countries and sectors are similar)

- customer-centric, vision-driven leadership (exploratory or confirmatory criteria: countries and sectors are similar)

- customer-centric business design (exploratory criterion: countries and sectors are similar)

- overall world class criterion (exploratory criterion: countries and sectors are similar).

Organisations as unit of analysis

The presence of a world class criterion in the organisation using organisations as unit of analysis: Comparing developed vs developing countries as well a primary vs secondary sectors are given in Table 4 and Table 5. According to Tables 4 and 5 the testing of the propositions using organisations as unit of analysis produced the following results:

Rejected propositions: World class criteria differed between countries and/or sectors:

TABLE 3

Individual respondents as unit of analysis: primary versus secondary sectors irrespective of developed/developing country status

\begin{tabular}{|c|c|c|c|c|c|c|c|c|c|c|}
\hline \multirow{2}{*}{ Criterion } & \multirow{2}{*}{ Factor (Criterion description) } & \multirow{2}{*}{$\begin{array}{l}\text { Moderating } \\
\text { variables }\end{array}$} & \multicolumn{3}{|c|}{ Descriptive } & \multicolumn{3}{|c|}{ Statistical significance } & \multirow{2}{*}{$\begin{array}{c}\text { Effect size: } \\
\text { Practical } \\
\text { significance }\end{array}$} & \multirow{2}{*}{$\begin{array}{l}\text { Effect } \\
\text { size: } \\
\text { Coded }\end{array}$} \\
\hline & & & $N$ & Mean & s.d. & $\begin{array}{c}\text { Mann- } \\
\text { Whitney U }\end{array}$ & $\begin{array}{c}\text { Wilcoxon } \\
\text { W }\end{array}$ & $P$ Value & & \\
\hline \multirow{2}{*}{ Exploratory } & \multirow{2}{*}{$\begin{array}{l}1 \text { Innovative, learning based } \\
\text { partnering }\end{array}$} & Primary & 196 & 3.4468 & 0.61584 & \multirow{2}{*}{-1.123} & \multirow{2}{*}{422.000} & \multirow{2}{*}{0.262} & \multirow{2}{*}{0.055} & \multirow{2}{*}{ None } \\
\hline & & Secondary & 228 & 3.5175 & 0.67244 & & & & & \\
\hline \multirow{2}{*}{ Exploratory } & \multirow{2}{*}{2 Powerful branding } & Primary & 197 & 3.4396 & 0.70844 & \multirow{2}{*}{-1.433} & \multirow{2}{*}{416.957} & \multirow{2}{*}{0.153} & \multirow{2}{*}{0.068} & \multirow{2}{*}{ None } \\
\hline & & Secondary & 228 & 3.5535 & 0.92700 & & & & & \\
\hline \multirow{2}{*}{ Exploratory } & \multirow{2}{*}{$\begin{array}{l}3 \begin{array}{l}\text { Performance and reward } \\
\text { driven people }\end{array}\end{array}$} & Primary & 197 & 3.4247 & 0.87715 & \multirow{2}{*}{-0.451} & \multirow{2}{*}{423.000} & & \multirow{2}{*}{0.214} & \\
\hline & & Secondary & 228 & 3.7968 & 0.82136 & & & & & \\
\hline \multirow{2}{*}{ Exploratory } & \multirow{2}{*}{$\begin{array}{l}\text { Customer centric, shared } \\
\text { vision driven leadership }\end{array}$} & Primary & 196 & 3.6780 & 0.65478 & \multirow{2}{*}{-0.137} & \multirow{2}{*}{423.000} & \multirow{2}{*}{0.891} & \multirow{2}{*}{0.007} & \multirow{2}{*}{ None } \\
\hline & & Secondary & 229 & 3.6870 & 0.69872 & & & & & \\
\hline Exploratory & 5 Customer centric business & Primary & 196 & 3.5680 & 0.80342 & -1.125 & 422.000 & 0.261 & 0.055 & None \\
\hline & design & Secondary & 228 & 3.6594 & 0.85826 & & & & & \\
\hline Exploratory & World class & Primary & 195 & 3.5339 & 0.55624 & -1.610 & 421.000 & 0.108 & 0.078 & None \\
\hline Expordatory & vouric ciass & Secondary & 228 & 3.6283 & 0.63724 & -1.010 & $4 \angle 1.000$ & & & \\
\hline Confirmatory & Ongoing stretch and future- & Primary & 197 & 3.7137 & 0.70019 & 0266 & 424000 & 0791 & 0.013 & None \\
\hline & driven strategising & Secondary & 229 & 3.6952 & 0.73187 & & & & & \\
\hline Confirmator & Customer-centric, process- & Primary & 196 & 3.6286 & 0.66902 & 0504 & (12) & 0614 & (2) & \\
\hline Comitimatory & $\begin{array}{l}4 \text { based, teaming organisation } \\
\text { architecture }\end{array}$ & Secondary & 228 & 3.6632 & 0.73350 & -0.504 & 422.000 & 0.614 & 0.025 & None \\
\hline Confirmator & An enabling and empowering & Primary & 197 & 3.1990 & 0.75741 & 3506 & 123 & & 172 & \\
\hline Contirmatory & $\begin{array}{l}6 \text { people pmilosopny and } \\
\text { Practice }\end{array}$ & Secondary & 228 & 3.4832 & 0.75737 & -3.586 & $4 \angle 3.000$ & & $0.1 / 2$ & \\
\hline & $\begin{array}{l}\text { Powerful internal and } \\
\text { external branding to build }\end{array}$ & Primary & 197 & 3.4396 & 0.70844 & & & & & \\
\hline Confirmatory & $\begin{array}{l}7 \text { and support a strong } \\
\text { organisation identity }\end{array}$ & Secondary & 228 & 3.5535 & 0.92700 & -1.433 & 416.957 & 0.531 & 0.068 & None \\
\hline
\end{tabular}


TABLE 4

Organisations as unit of analysis: Developed versus developing countries

\begin{tabular}{|c|c|c|c|c|c|c|c|c|c|c|}
\hline \multirow[b]{2}{*}{ Criterion } & \multirow[b]{2}{*}{ Factor (Criterion description) } & \multirow[b]{2}{*}{$\begin{array}{l}\text { Moderating } \\
\text { variables }\end{array}$} & \multicolumn{3}{|c|}{ Descriptive } & \multicolumn{3}{|c|}{ Statistical significance } & \multirow{2}{*}{$\begin{array}{c}\text { Effect size: } \\
\text { Practical } \\
\text { significance }\end{array}$} & \multirow{2}{*}{$\begin{array}{l}\text { Effect } \\
\text { size: } \\
\text { Coded }\end{array}$} \\
\hline & & & $N$ & Mean & s.d. & $\begin{array}{c}\text { Mann- } \\
\text { Whitney-U }\end{array}$ & $\begin{array}{c}\text { Wilcoxon } \\
\text { W }\end{array}$ & $P$ Value & & \\
\hline \multirow{2}{*}{ Exploratory } & \multirow{2}{*}{$\begin{array}{l}\text { Innovative, learning based } \\
\text { partnering }\end{array}$} & Developed & 11 & 3.4810 & 0.55895 & \multirow{2}{*}{52.000} & \multirow{2}{*}{118.000} & \multirow{2}{*}{0.577} & \multirow{2}{*}{0.116} & \multirow{2}{*}{ Small } \\
\hline & & Developing & 11 & 3.3783 & 0.33105 & & & & & \\
\hline \multirow{2}{*}{ Exploratory } & \multirow{2}{*}{2 Powerful branding } & Developed & 11 & 3.3786 & 0.44780 & \multirow{2}{*}{58.000} & \multirow{2}{*}{124.000} & \multirow{2}{*}{0.870} & \multirow{2}{*}{0.023} & \multirow{2}{*}{ None } \\
\hline & & Developing & 11 & 3.3565 & 0.51102 & & & & & \\
\hline \multirow{2}{*}{ Exploratory } & \multirow{2}{*}{$\begin{array}{l}3 \text { Performance and reward } \\
\text { driven people }\end{array}$} & Developed & 11 & 3.8105 & 0.49126 & \multirow{2}{*}{33.000} & \multirow{2}{*}{99.000} & \multirow{2}{*}{0.071} & \multirow{2}{*}{0.390} & \\
\hline & & Developing & 11 & 3.4198 & 0.47620 & & & & & \\
\hline \multirow{2}{*}{ Exploratory } & \multirow{2}{*}{$\begin{array}{l}\text { Customer centric, shared } \\
\text { vision driven leadership }\end{array}$} & Developed & 11 & 3.84 & 0.32357 & \multirow{2}{*}{40.500} & \multirow{2}{*}{106.500} & \multirow{2}{*}{0.189} & & \\
\hline & & Developing & 11 & & 0.37683 & & & & $0.3 / 0$ & \\
\hline & Customer centric business & Developed & 11 & 3.5745 & 0.59955 & & & & & \\
\hline Exploratory & ${ }^{3}$ design & Developing & 11 & 3.4809 & 0.42838 & 59.500 & 125.500 & 0.948 & 0.094 & None \\
\hline Exploratory & World class & Developed & 11 & 3.6392 & 0.36039 & 50000 & 116.000 & 0.491 & 0252 & Sma \\
\hline y & 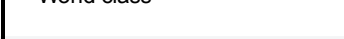 & Developing & 11 & 3.4567 & 0.37361 & 00.000 & 10.000 & (2.70 & 0.202 & Sivin \\
\hline Confirmatory & 1 Ongoing stretch and future- & Developed & 8 & 3.916 & 0.38556 & 24.000 & 69.000 & 0.248 & 0.359 & \\
\hline & & Developing & 9 & 3.6728 & 0.28637 & & & & & \\
\hline & Customer-centric, process- & Developed & 8 & 3.6246 & 0.52758 & 20 & 61000 & & & \\
\hline Contirmatory & $\begin{array}{l}4 \text { based, teaming organisation } \\
\text { architecture }\end{array}$ & Developing & 9 & 3.6637 & 0.24571 & 28.000 & 64.000 & 0.441 & 0.051 & None \\
\hline Confirmatory & An enabling and empowering & Developed & 8 & 3.54 & 0.38659 & 18000 & 63000 & 0.083 & 0.422 & \\
\hline & Practice & Developing & 9 & & 0.41212 & & & & & \\
\hline & Powerful internal and & & & & & & & & & \\
\hline Confirmatory & 7 external branding to build & Developed & 0 & 3.3231 & 0.49140 & 28.000 & 64.000 & 0.441 & 0.181 & Small \\
\hline & organisation identity & Developing & 9 & 3.4772 & 0.39417 & & & & & \\
\hline
\end{tabular}

s.d., standard deviation.

TABLE 5

Organisations as unit of analysis: primary versus secondary sectors irrespective of developing/developed country status

\begin{tabular}{|c|c|c|c|c|c|c|c|c|c|c|}
\hline \multirow[b]{2}{*}{ Criterion } & \multirow[b]{2}{*}{ Factor (Criterion description) } & \multirow[b]{2}{*}{$\begin{array}{l}\text { Moderating } \\
\text { variables }\end{array}$} & \multicolumn{3}{|c|}{ Descriptive } & \multicolumn{3}{|c|}{\begin{tabular}{|c|} 
Statistical significance \\
\end{tabular}} & \multirow[b]{2}{*}{$\begin{array}{l}\text { Effect size: } \\
\text { Statistical }\end{array}$} & \multirow{2}{*}{$\begin{array}{l}\text { Effect } \\
\text { size: } \\
\text { Coded }\end{array}$} \\
\hline & & & $N$ & Mean & s.d. & \begin{tabular}{|c|} 
Mann- \\
Whitney U \\
\end{tabular} & $\begin{array}{c}\text { Wilcoxon } \\
\text { W }\end{array}$ & $P$ Value & & \\
\hline Exploratory & $\begin{array}{l}\text { Innovative, learning based } \\
\text { partnering }\end{array}$ & $\begin{array}{l}\text { Primary } \\
\text { Secondary }\end{array}$ & $\begin{array}{l}11 \\
11\end{array}$ & $\begin{array}{l}3.5177 \\
3.3416\end{array}$ & $\begin{array}{l}0.32497 \\
0.55241\end{array}$ & 49.000 & 115.000 & 0.450 & 0.200 & Small \\
\hline Exploratory & 2 Powerful branding & $\begin{array}{l}\text { Primary } \\
\text { Secondary }\end{array}$ & $\begin{array}{l}11 \\
11\end{array}$ & $\begin{array}{l}3.4737 \\
3.6140\end{array}$ & $\begin{array}{l}0.33736 \\
0.59235\end{array}$ & 46.000 & 112.000 & 0.341 & 0.225 & Small \\
\hline Exploratory & $\begin{array}{l}3 \text { Performance and reward } \\
\text { driven people }\end{array}$ & $\begin{array}{l}\text { Primary } \\
\text { Secondary }\end{array}$ & $\begin{array}{l}11 \\
11\end{array}$ & $\begin{array}{l}3.5538 \\
3.6764\end{array}$ & $\begin{array}{l}0.58446 \\
. .44965\end{array}$ & 51.500 & 117.500 & 0.554 & 0.122 & Small \\
\hline Exploratory & $\begin{array}{l}\text { Customer centric, shared } \\
\text { vision driven leadership }\end{array}$ & $\begin{array}{c}\text { Primary } \\
\text { Secondary }\end{array}$ & $\begin{array}{l}11 \\
11\end{array}$ & $\begin{array}{l}3.7957 \\
3.6262\end{array}$ & $\begin{array}{l}0.35426 \\
0.38023\end{array}$ & 49.500 & 115.500 & 0.470 & 0.235 & Small \\
\hline Exploratory & $\begin{array}{l}5 \text { Customer centric business } \\
\text { design }\end{array}$ & $\begin{array}{l}\text { Primary } \\
\text { Secondary }\end{array}$ & $\begin{array}{l}11 \\
11\end{array}$ & $\begin{array}{l}3.6064 \\
3.4491\end{array}$ & $\begin{array}{l}0.51713 \\
0.51649\end{array}$ & 47.000 & 113.000 & 0.375 & 0.158 & Small \\
\hline Exploratory & World class & $\begin{array}{l}\text { Primary } \\
\text { Secondary }\end{array}$ & $\begin{array}{l}11 \\
11\end{array}$ & $\begin{array}{l}3.6251 \\
3.4708\end{array}$ & $\begin{array}{l}0.34326 \\
0.39607\end{array}$ & 47.000 & 113.000 & 0.375 & 0.213 & Small \\
\hline Confirmatory & $\begin{array}{l}1 \text { Ongoing stretch and future- } \\
\text { driven strategising }\end{array}$ & $\begin{array}{l}\text { Primary } \\
\text { Secondary }\end{array}$ & $\begin{array}{l}9 \\
8\end{array}$ & $\begin{array}{l}3.8213 \\
3.7495\end{array}$ & $\begin{array}{l}0.44045 \\
0.23117\end{array}$ & 34.000 & 79.000 & 0.847 & 0.106 & Small \\
\hline Confirmatory & $\begin{array}{l}\text { Customer-centric, process- } \\
4 \text { based, teaming organisation } \\
\text { architecture }\end{array}$ & $\begin{array}{l}\text { Primary } \\
\text { Secondary }\end{array}$ & $\begin{array}{l}9 \\
8\end{array}$ & $\begin{array}{l}3.6783 \\
3.6082\end{array}$ & $\begin{array}{l}0.40151 \\
0.40130\end{array}$ & 31.000 & 67.000 & 0.630 & 0.092 & None \\
\hline Confirmatory & $\begin{array}{l}\text { An enabling and empowering } \\
6 \text { people philosophy and } \\
\text { Practice }\end{array}$ & $\begin{array}{l}\text { Primary } \\
\text { Secondary }\end{array}$ & $\begin{array}{l}9 \\
8\end{array}$ & $\begin{array}{l}3.2619 \\
3.4615\end{array}$ & $\begin{array}{l}0.48543 \\
0.35267\end{array}$ & 24.500 & 69.500 & 0.268 & 0.240 & Small \\
\hline Confirmatory & $\begin{array}{l}\text { Powerful internal and } \\
\text { external branding to build } \\
\text { and support a strong } \\
\text { organisation identity }\end{array}$ & $\begin{array}{l}\text { Primary } \\
\text { Secondary }\end{array}$ & $\begin{array}{l}9 \\
8\end{array}$ & $\begin{array}{l}3.4180 \\
3.3896\end{array}$ & $\begin{array}{l}0.30622 \\
0.57599\end{array}$ & 34.000 & 70.000 & 0.847 & 0.033 & None \\
\hline
\end{tabular}




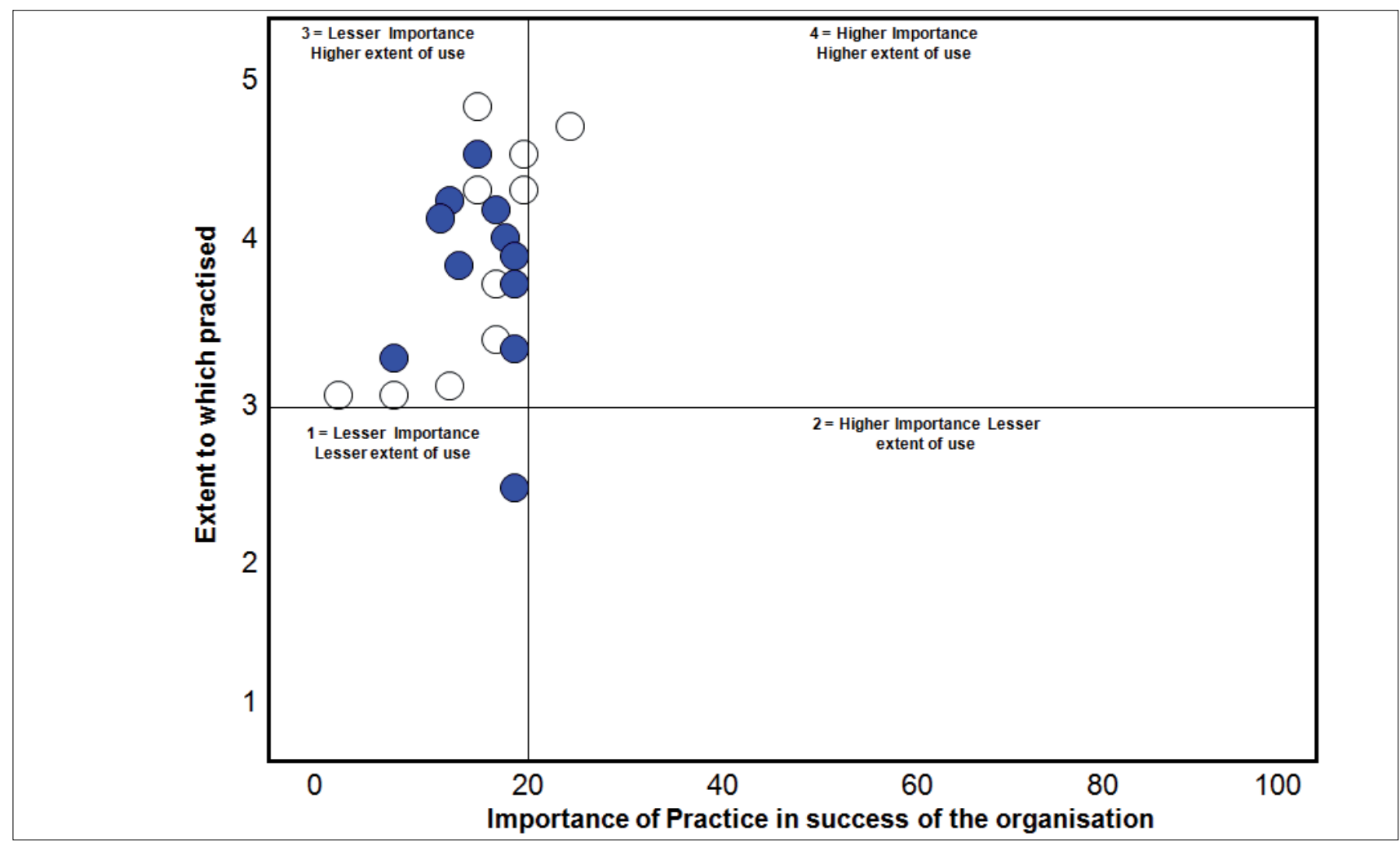

FIGURE 2

Scatter plot example for practice 3.5: Partnering with our stakeholders drives continuous improvement and innovation for everyone, as indicated in Table 1

- performance-and reward-driven people (exploratory criterion: developed countries higher than developing countries)

- ongoing stretch and future-driven strategising (confirmatory criterion: developed countries higher than developing countries)

- enabling and empowering people philosophy and practices (confirmatory criterion: developed countries higher than developing countries)

- customer-centric, shared vision-driven leadership (exploratory criterion: developed countries higher than developing countries).

The effect size that is the practical significance, in all cases was medium.

Accepted propositions: World class criteria are the same across countries and/or sectors:

- innovative, learning based partnering (exploratory criterion: countries are similar)

- powerful branding (exploratory or confirmatory criteria: countries are similar)

- customer-centric business design (exploratory or confirmatory criteria: countries are similar)

- overall world class criterion (exploratory criterion: countries are similar).

In all instances the industries were the same on all of the criteria.

From the above, the following trends appear to hold with respect to the above results, (1) both in the case of individuals and organisations as units of analysis, a number of world criteria (between 3 and 4 criteria) are seen as more present in organisations from developed than from developing countries. It appears as if these differentiating criteria are more peoplerelated criteria (e.g. rewards, people philosophy and practices), (2) the effect size of these significant differences are greater when organisations are the unit of analysis, (3) the criteria that are similar across developing and developed countries (also between 3 and 4 ) appear to relate more to the organisation as a whole (e.g. branding, design) and (4) criteria across sector (i.e. primary vs secondary) appear to be the same. (i.e. criteria do not apply differentially to sectors).

\section{Practices in the success of the organisation}

A scatter plot was created where the $\mathrm{X}$-axis measured the importance of a practice in the success of the organisation and where the Y-axis measured the extent of practice. Four quadrants were created on the scatter plot as given in the example in Figure 2.

As illustrated in Figure 2, a cut-off point of 20 was chosen as the norm since 20 out of a maximum of 100 points would represent equal weight to each of the practice in the five practice sets related to a criterion. More than 20 points therefore indicates a higher level of importance of a practice to perceived business success in the organisation and vice versa. Each quadrant was numbered with a corresponding description. Bullets with no fill represent organisations in developed countries whilst filled bullets represented organisations in developing countries. The practices associated with the exploratory criteria, firstly, were plotted individually on histograms and secondly were grouped in tables by exploratory world class criteria. This enabled the researchers to analyse each practice individually and subsequently the world class criterion as a whole as it related to the research propositions of the study.

The outcomes of the analyses of practices plotted on histograms were as follows as summarised in the right hand column of Table 7 (the balance of this table will be dealt with in the discussion section below). As can been seen from Table 7 there were significant differences between developed and developing countries in a number of practices applied. The majority of differences in practices occurred with respect to customer-centric, shared vision-driven leadership and ongoing stretch and future driven strategising.

\section{Statistically based grouping of organisations}

The grouping of organisations into developed and developing countries which guided the foregoing analyses were done 


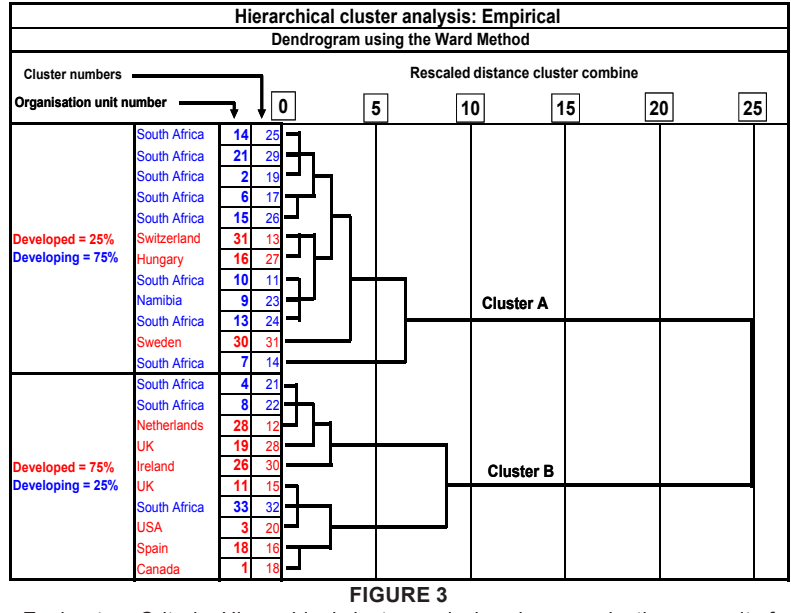

Exploratory Criteria: Hierarchical cluster analysis using organisations as unit of analysis

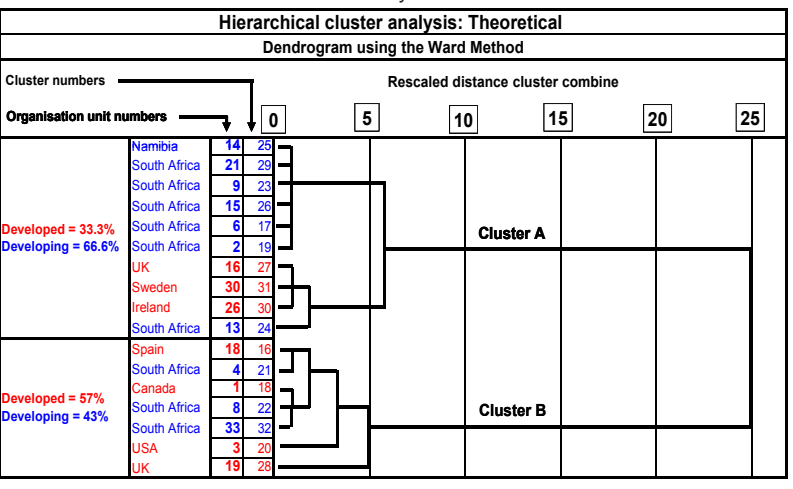

FIGURE 4

Confirmatory Criteria: Hierarchical cluster analysis using organisations as unit of analysis on the basis of the physical location of the participating organisations. The guiding assumption of this categorisation is that the actual physical country location of an organisation determines whether an organisation is world class or not. The validity of this assumption was investigated by using cluster analysis to determine the statistical grouping of the organisations surveyed (i.e. not to assume world class equates to a physical location, namely developed or developing country). The resultant clusters were used to test the acceptance or rejection of the propositions.

The results, where a country name anonymously represented an organisation, are portrayed in Figures 3 and 4 respectively for the exploratory and confirmatory criteria.

The cluster analysis for the exploratory criteria yielded a more definitive trend in terms of differences between developed and developing countries than in the case of the confirmatory criteria. Two distinct new categories of world class organisations emerged: Category A (from cluster A) which contained 75\% of organisations from developing countries and $25 \%$ from developed countries. Category A was labeled as 'trailing world class organisations' implying a less advanced or mature level of being world class. Category B (from cluster B) contained $70 \%$ of organisations from developed countries and $30 \%$ from developing countries. Category B was labeled as 'Leading world class organisations' implying a more advanced mature level of being world class. The strength of using the clustering based on the exploratory criteria is that these criteria were determined empirically, which corresponds with the empirical grouping of organisations into world class or not.

A retest of the propositions using Category A versus Category B using organisations as unit of analysis are depicted in the fourth column of results give in Table 6.

Evident from Table 6 is the need to qualify the previous results based on using physical location as a means of categorisation

TABLE 6

Exploratory Criteria: Category A (Developing) compared with Category B (Developed)

\begin{tabular}{|c|c|c|c|c|c|c|c|c|c|c|}
\hline \multirow[b]{2}{*}{ Criterion } & \multirow[b]{2}{*}{ Factor (Criterion description) } & \multirow[b]{2}{*}{$\begin{array}{l}\text { Moderating } \\
\text { variables }\end{array}$} & \multicolumn{3}{|c|}{ Descriptive } & \multicolumn{3}{|c|}{ Statistical significance } & \multirow{2}{*}{$\begin{array}{l}\text { Effect size: } \\
\text { Practical } \\
\text { significance }\end{array}$} & \multirow{2}{*}{$\begin{array}{l}\text { Effect } \\
\text { size: } \\
\text { Coded }\end{array}$} \\
\hline & & & $N$ & Mean & s.d. & $\begin{array}{c}\text { Mann- } \\
\text { Whitney U } \\
\end{array}$ & $\begin{array}{c}\text { Wilcoxon } \\
\text { W }\end{array}$ & $P$ Value & & \\
\hline Exploratory & $\begin{array}{l}1 \text { Innovative, learning based } \\
\text { partnering }\end{array}$ & $\begin{array}{l}\text { Developed* }^{*} \\
\text { Developing }^{*}\end{array}$ & $\begin{array}{l}10 \\
12\end{array}$ & $\begin{array}{l}3.7901 \\
3.1292\end{array}$ & $\begin{array}{l}0.28957 \\
0.32207\end{array}$ & 3.000 & 81.000 & 0.000 & 0.746 & \\
\hline Exploratory & 2 Powerful branding & $\begin{array}{l}\text { Developed* }^{*} \\
\text { Developing* }\end{array}$ & $\begin{array}{l}10 \\
12\end{array}$ & $\begin{array}{l}3.7219 \\
3.0722\end{array}$ & $\begin{array}{l}0.37874 \\
0.34427\end{array}$ & 14.000 & 92.000 & 0.002 & 0.686 & arge \\
\hline Exploratory & $\begin{array}{l}3 \text { Performance and reward } \\
\text { driven people }\end{array}$ & $\begin{array}{l}\text { Developed* } \\
\text { Developing* }\end{array}$ & $\begin{array}{l}10 \\
12\end{array}$ & $\begin{array}{l}3.9714 \\
3.3183\end{array}$ & $\begin{array}{l}0.41993 \\
0.38222\end{array}$ & 13.500 & 91.500 & 0.002 & 0.649 & \\
\hline Exploratory & 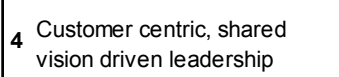 & $\begin{array}{l}\text { Developed* }^{*} \\
\text { Developing* }\end{array}$ & $\begin{array}{l}10 \\
12\end{array}$ & 3.4800 & $\begin{array}{l}0.24176 \\
0.28995\end{array}$ & 6.500 & 84.500 & 0.000 & 0.702 & \\
\hline Exploratory & $\begin{array}{l}5 \text { Customer centric business } \\
\text { design }\end{array}$ & $\begin{array}{l}\text { Developed* } \\
\text { Developing* }\end{array}$ & $\begin{array}{l}10 \\
12\end{array}$ & $\begin{array}{l}3.7946 \\
3.3053\end{array}$ & $\begin{array}{l}0.54722 \\
0.36644\end{array}$ & 30.500 & 108.500 & 0.051 & 0.488 & \\
\hline Exploratory & World class & $\begin{array}{l}\text { Developed* }^{*} \\
\text { Developing* }^{*}\end{array}$ & $\begin{array}{l}10 \\
12\end{array}$ & $\begin{array}{l}3.8741 \\
3.2762\end{array}$ & $\begin{array}{l}0.20554 \\
0.22315\end{array}$ & 0.000 & 78.000 & 0.000 & 0.832 & Large \\
\hline Exploratory & $\begin{array}{l}1 \text { Innovative, learning based } \\
\text { partnering }\end{array}$ & $\begin{array}{l}\text { Developed } \\
\text { Developing }\end{array}$ & $\begin{array}{l}138 \\
286\end{array}$ & $\begin{array}{l}3.5321 \\
3.4620\end{array}$ & $\begin{array}{l}0.6400 \\
0.6504\end{array}$ & 1.045 & 422.000 & 0.297 & 0.051 & None \\
\hline Exploratory & 2 Powerful Branding & $\begin{array}{l}\text { Developed } \\
\text { Developing }\end{array}$ & $\begin{array}{l}139 \\
286\end{array}$ & $\begin{array}{l}3.4921 \\
3.5049\end{array}$ & $\begin{array}{l}0.7679 \\
0.8653\end{array}$ & -0.148 & 423.000 & 0.882 & 0.007 & None \\
\hline Exploratory & $3 \begin{array}{l}\text { Performance and reward } \\
\text { driven people }\end{array}$ & $\begin{array}{l}\text { Developed } \\
\text { Developing }\end{array}$ & $\begin{array}{l}139 \\
286\end{array}$ & $\begin{array}{l}3.8010 \\
3.5385\end{array}$ & $\begin{array}{l}0.7809 \\
0.8944\end{array}$ & 2.955 & 423.000 & 0.003 & 0.142 & \\
\hline Exploratory & $\begin{array}{l}\text { Customer centric, shared } \\
\text { vision driven leadership }\end{array}$ & $\begin{array}{l}\text { Developed } \\
\text { Developing }\end{array}$ & $\begin{array}{l}139 \\
286\end{array}$ & $\begin{array}{l}3.7762 \\
3.6375\end{array}$ & $\begin{array}{l}0.5575 \\
0.7261\end{array}$ & 2.171 & 345.589 & 0.031 & 0.096 & None \\
\hline Exploratory & $\begin{array}{l}5 \text { Customer centric business } \\
\text { design }\end{array}$ & $\begin{array}{l}\text { Developed } \\
\text { Developing }\end{array}$ & $\begin{array}{l}139 \\
286\end{array}$ & $\begin{array}{l}3.6594 \\
3.5967\end{array}$ & $\begin{array}{l}0.8130 \\
0.8441\end{array}$ & 0.725 & 422.000 & 0.496 & 0.035 & None \\
\hline Exploratory & World class & $\begin{array}{l}\text { Developed } \\
\text { Developing }\end{array}$ & $\begin{array}{l}137 \\
286\end{array}$ & $\begin{array}{l}3.6534 \\
3.5519\end{array}$ & $\begin{array}{l}0.5460 \\
0.6259\end{array}$ & 1.625 & 421.000 & 0.105 & 0.079 & None \\
\hline
\end{tabular}

s.d., standard deviation. 
with organisations as unit of analysis. Whereas only two propositions from the original exploratory criteria were rejected, all five exploratory criteria were rejected with notable differences in both statistical significance and practical effect size, the latter moving from a medium to a large effect size. All five exploratory criteria, as well as the overall world class criterion, significantly differentiated in the presence of the criteria between developing and developed countries with the former significantly higher than the latter. The implication of this finding is that the cluster analysis removed the overriding 'noise' of using physical location as pre-set category determinate.

Two new categories of organisations emerged from the cluster analysis: 'leading' and 'trailing' world class organisations:

- Thirty per cent of developing-country, world class companies have already made the transition to becoming world class organisations.

- Twenty-five per cent of developed country companies have yet to become 'developed' world class organisations.

This result thus demonstrated that physical location does play the dominant role in being world class. But this has to be qualified since there also are world class organisations in developing countries, although in the minority. Inversely, non-world class organisations exist in developed countries, although in the minority.

\section{DISCUSSION}

Prior to proceeding with discussing the results reported above, answers to the following questions are required in order to focus the discussion appropriately, firstly, should individual respondents or organisations as unit of analysis be used in the discussion and interpretation below or are both eligible?, secondly, should the differences in world class criteria in respect of primary versus secondary sectors where individuals are the unit of analysis be taken into account in the discussion and interpretation?, thirdly, should the outcomes of the proposition tested given in Table 6, based on the cluster analysis where organisations were grouped as leading and trailing world class organisations be taken into account?

The reported results are summarised in Table 7 to provide answers to the above questions.

The horizontal blocks in bold in Table 7 highlight where propositions in respect of the extent of use a practice (i.e. the presence of a criterion) were accepted or rejected as well as where differences in extent of practice by importance between developed and developing countries appear within the same criterion. The two vertical pointed block arrows in bold in Table 7 encapsulate the majority of propositions rejected $(\sqrt{ }=$ proposition accepted, $x=$ proposition rejected $)$.

As shown in Table 7, the majority of rejected propositions are in respect of the exploratory and confirmatory criteria where organisations were the unit of analysis (indicated by the vertical green block arrow in Table 7). In the literature the discussion also focuses on how organisations collectively think and act and not so much the individual. The reported empirical results of this study confirm the appropriateness of the organisation as unit of analysis and that the interpretation and discussion should proceed where organisations, instead of individuals, are the unit of analysis.

\begin{tabular}{|c|c|c|c|c|c|c|c|c|c|}
\hline \\
\hline & & & \multicolumn{5}{|c|}{ Extent of Practice collectively within a Criterion } & \multirow{2}{*}{\multicolumn{2}{|c|}{$\begin{array}{l}\text { Extent of Practice by Importance } \\
\text { (Organisations as unit of analysis) }\end{array}$}} \\
\hline & & & \multicolumn{2}{|c|}{$\begin{array}{l}\text { Individuals as unit of } \\
\text { analysis }\end{array}$} & \multicolumn{3}{|c|}{ Organisations as unit of analysis } & & \\
\hline Criterion & & Criterion description & $\begin{array}{l}\text { Developed } \\
\text { countries } \\
\text { Developing } \\
\text { countries }\end{array}$ & $\begin{array}{l}\text { Primary } \\
\text { Sector } \\
\text { Secondary } \\
\text { Sector }\end{array}$ & $\begin{array}{c}\text { Developed } \\
\text { countries } \\
\text { Developing } \\
\text { countries }\end{array}$ & $\begin{array}{l}\text { Primary } \\
\text { Sector } \\
\text { Secondary } \\
\text { Sector }\end{array}$ & $\begin{array}{c}\text { Group B = } \\
\text { Leading } \\
\text { Group A = } \\
\text { Trailing }\end{array}$ & $\begin{array}{c}\text { Significant } \\
\text { differences } \\
\text { favouring } \\
\text { Developed } \\
\text { countries }\end{array}$ & $\begin{array}{c}\text { Significant } \\
\text { differences } \\
\text { favouring } \\
\text { Developing } \\
\text { countries }\end{array}$ \\
\hline Exploratory & & $\begin{array}{l}\text { Innovative, learning based } \\
\text { partnering }\end{array}$ & $\sqrt{ }$ & & & & ses & 6.2 & $5.3 ; 4.4$ \\
\hline Exploratory & 2 & Powerful branding & $\sqrt{ }$ & $\sqrt{ }$ & $\sqrt{ }$ & $\checkmark$ & $\boldsymbol{x}$ & - & - \\
\hline Exploratory & & $\begin{array}{l}\text { Performance and reward driven } \\
\text { people }\end{array}$ & $\boldsymbol{s}$ & $\boldsymbol{x}$ & $\boldsymbol{x}$ & & $\boldsymbol{x}$ & 6.4 & - \\
\hline Exploratory & & $\begin{array}{l}\text { Customer-centric, shared } \\
\text { vision driven leadership }\end{array}$ & & & $\boldsymbol{x}$ & & $x$ & $1.1 ; 1.4 ; 1.5$ & \\
\hline Exploratory & & $\begin{array}{l}\text { Customer-centric business } \\
\text { design }\end{array}$ & $\checkmark$ & $\sqrt{ }$ & $\sqrt{ }$ & & $\boldsymbol{x}$ & 4.1 & - \\
\hline Exploratory & & World class & $\sqrt{ }$ & $\checkmark$ & $\checkmark$ & $\sqrt{ }$ & $x$ & - & - \\
\hline Confirmatory & & $\begin{array}{l}\text { Ongoing stretch and future- } \\
\text { driven strategising }\end{array}$ & $\boldsymbol{x}$ & & $\boldsymbol{x}$ & $\sqrt{ }$ & - & $1.1 ; 1.4 ; 1.5$ & - \\
\hline Confirmatory & & $\begin{array}{l}\text { Customer-centric, process- } \\
\text { based, teaming organisation } \\
\text { architecture }\end{array}$ & $\sqrt{ }$ & & $\sqrt{ }$ & & - & 4.1 & 4.4 \\
\hline Confirmatory & & $\begin{array}{l}\text { An enabling and empowering } \\
\text { people philosophy a practice }\end{array}$ & $\boldsymbol{x}$ & $\boldsymbol{x}$ & $\boldsymbol{x}$ & $\checkmark$ & - & $6.2 ; 6.4$ & - \\
\hline Confirmatory & 7 & $\begin{array}{l}\text { Powerful internal and external } \\
\text { branding to build and support a } \\
\text { strong organisation identity }\end{array}$ & & & $\checkmark$ & & - & - & - \\
\hline
\end{tabular}


With respect to primary and secondary sector organisations, all of the propositions were accepted where these were the unit of analysis. This confirmed that exploratory and confirmatory world class criteria are the same, irrespective of whether organisations are in the primary or secondary sector. Since it was decided to proceed where organisations are the unit of analysis the significant differences found in primary versus secondary sectors where individuals are the unit of analysis were therefore put aside for the purposes of the discussion and interpretation below. The emphasis would be on developed versus developing countries.

The results of the cluster analysis demonstrated that physical location is of secondary concern since leading world class organisations are present in both developed and developing countries whereas trailing world class organisations are also to be found across these countries. The 'lesser' impact of physical location on being world class hence has to be taken into account. Therefore the regrouping of organisations resulting from the cluster analysis will be included in the discussion below.

The discussion and interpretation of the results centre around the following topics, firstly, a confirmation through this study of what is already known in the existing literature, secondly, the validity of world class criteria across developed and developing countries, thirdly, gaps in the existing knowledge closed by the study, and lastly, a proposed reconstituted model of world class criteria or practices in developed and developing countries respectively.

\section{Literature Review}

A confirmation of what is already known in the existing literature regarding world class organisations
Table 8 provides a summarised list of empirically confirmed and unconfirmed practices by criterion as reported in the literature review section. This summary enables a comparison to be made with the practices identified through the literature review. A high level of empirical confirmation means that a practice was confirmed both as an exploratory and confirmatory criterion, a medium level that a practice was confirmed empirically either being part of an exploratory or confirmatory criterion, and low or non-significant that there was insufficient statistical evidence to confirm this practice as part of a criterion - whilst it does occur, its incidence was found to be very low.

According to Table $8,85.7 \%$ of the world class practices as seen in use and important in the literature reviewed, could empirically be confirmed in the study, leaving $14.3 \%$ of the practices empirically unconfirmed. The implications of this finding may be that not all world class practices are applied consistently all the time by all organisations purported to be world class or which are ascending to becoming world class.

In terms of Table 8 empirical confirmation through this study of what exists in literature is discussed next.

\section{Literature Criterion 1: Ongoing stretch and future- driven strategising}

The empirical confirmation of practices 1.1 to 1.5 associated with criterion 1 (e.g. Beer, 2009; Browne, 2003; Collins \& Porras, 2002; Joyce, 2005; Nel \& Beudeker, 2009: Veldsman, 2002) was high (see Table 8). It can be argued that this confirmation can be found in the competition for front line positions by world class organisations that know that they have to continually change and improve to meet changing customer needs and expectations as a way of life.

TABLE 8

List of confirmed and unconfirmed practices by criterion

\begin{tabular}{|c|c|c|c|c|}
\hline & \multirow{2}{*}{$\begin{array}{c}\text { Literature } \\
1.1\end{array}$} & \multicolumn{2}{|r|}{ Confirmation in Literature High; Medium; Low/not at all } \\
\hline \multirow{35}{*}{ 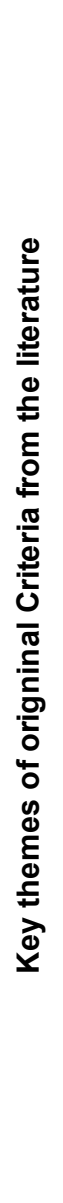 } & \multirow{5}{*}{ 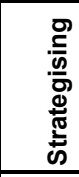 } & & High & strategising is about creating a desired future \\
\hline & & 1.2 & High & strategising is an ongoing process throughout the year \\
\hline & & 1.3 & High & strategies rapidly change to meet changing customer needs \\
\hline & & 1.4 & High & strategies are shared and owned by everyone \\
\hline & & 1.5 & High & strategies stretch us beyond what we believe is currently possible \\
\hline & \multirow{5}{*}{ 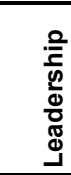 } & 2.1 & Medium & leadership drives continual change \\
\hline & & 2.2 & Medium & leadership focuses on creating something new \\
\hline & & 2.3 & Medium & leadership "thinks out of the box" \\
\hline & & 2.4 & Medium & leadership ensures that everyone shares the same future \\
\hline & & 2.5 & Low/not & everone is expected to show leadership \\
\hline & \multirow{5}{*}{ 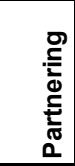 } & 3.1 & Medium & all our stakeholders partner with us in our business \\
\hline & & 3.2 & Low/not & our people build close relationships with our customers \\
\hline & & 3.3 & Medium & people are seen as key to the success of our business \\
\hline & & 3.4 & Low/not & we both compete and collaborate with our competitors \\
\hline & & 3.5 & Medium & partnering with our stakeholders drives continuous improvement and innovation for everyone \\
\hline & \multirow{5}{*}{ 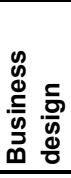 } & 4.1 & High & we think like our customers \\
\hline & & 4.2 & High & customer needs and expectations determine how we design our business processes \\
\hline & & 4.3 & High & our business processes are closely interconnected to serve our customers seamlessly \\
\hline & & 4.4 & High & core capabilities that enable business processes are built through ongoing learning \\
\hline & & 4.5 & Medium & teams are designed around business processes \\
\hline & \multirow{5}{*}{ 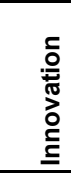 } & 5.1 & Low/not & good is never good enough \\
\hline & & 5.2 & Low/not & competitive standards are achieved through benchmarking against other organisations \\
\hline & & 5.3 & Medium & innovative ideas are born by working close to customers and suppliers \\
\hline & & 5.4 & Low/not & an inner urge for continuous improvement flows from what the organisation stands for \\
\hline & & 5.5 & Medium & leaps in innovation is the norm rather than the exception \\
\hline & \multirow{5}{*}{$\begin{array}{l}\frac{0}{0} \\
0 \\
0\end{array}$} & 6.1 & High & people development is driven by the organisation's desired future \\
\hline & & 6.2 & High & teaching and learning takes place ahead of change \\
\hline & & 6.3 & Medium & people are multiskilled and multitasked to enable their flexible deployment across the organisation \\
\hline & & 6.4 & High & real time performance feedback is ongoing with readily accessible performance information \\
\hline & & 6.5 & High & performance, reward and recognition are closely linked \\
\hline & \multirow{5}{*}{$\begin{array}{l}\text { D } \\
\frac{0}{0} \\
\frac{\pi}{0} \\
\frac{\pi}{0}\end{array}$} & 7.1 & High & our brand and what we stand for is understood by everyone in the organisation \\
\hline & & 7.2 & High & our brand is lived by everyone in our organisation in our day to day operations \\
\hline & & 7.3 & High & our brand is who and what we are, and what we stand for in the hearts and minds of our customers \\
\hline & & 7.4 & High & our brand is experienced the same way by all our stakeholders, internal and external to the organisation \\
\hline & & 7.4 & High & our brand delivers what it promises to our customers \\
\hline
\end{tabular}




\section{Literature Criterion 2: Transformational, distributed leadership}

The empirical confirmation of practices 2.1-2.4 of criterion 2 (e.g. Collins, 2001; Joyce, 2005; Krames, 2005; Nel \& Beudeker, 2009; Veldsman, 2002) was rated as medium (see Table 8). These practices, as they are reported on in the literature review, describe how leadership drives change, how they always create something new and how they think out of the box, ensuring that all their people share the same future. Although confirmation in the literature review was rated medium, these practices align with the race for 'front line positions' as in the literature criterion 1 . To stay ahead in the race, transformational leadership in world class organisations has to continually bring the 'new' into being and/or transform what exists into something new. Leadership that is continually driving for stretch goals is continually mobilising its followers in pursuance of possible desirable futures.

The empirical confirmation of practice 2.5: Everyone is expected to show leadership was rated as low or not at all. According to the literature review, though transformational leadership is pervasive in world class organisations, creating transformational thinking which drives innovation and change. Whilst the aim of the researchers was to test this practice with the statement everyone is expected to show leadership, it is the contention of the researchers that this statement was poorly formulated in the questionnaire and therefore may that have been not understood by the respondents as it was intended. It would be fallacious, therefore, to conclude that transformational leadership which is well spread through world class organisations, was not confirmed empirically as posited in the literature. The practice of transformational leadership being well spread throughout the organisation, according to literature, is so fundamental to the success of world class organisations that it cannot be judged as not being confirmed empirically on account of a poorly formulated statement.

\section{Literature Criterion 3: All-round ownership and partnering amongst all stakeholders \\ The empirical confirmation of practices 3.1, 3.3 and 3.5 of criterion 3 (e.g. Beer, 2009; Flannery, Hofrichter \& Platten, 1996; Simon, 2000; Stewart, 2006; Van Dyk \& Herholdt, 2003) was rated as medium (see Table 8). These three practices refer to stakeholder partnering, which drives continuous improvement where people are seen as key stakeholders in the business. The empirical confirmations of the following practices were rated as low/not at all, Practice 3.2: Our people build close relationships with our customers. A high standard deviation of 11.00 with respect to relative importance of the practice to the success of the organisation indicated that the practice of building close relationships with customers was perceived to be inconsistently practised within the world class organisations surveyed.}

It makes sense for an organisation to build close relationships with customers and to create the impression that they do. The result questions whether this is actually made standard practice by world class organisations. Another possible explanation is that because not all respondents have direct contact with the end customers of their organisation, they may not view relationship building with internal customers as important as with external customers.

Concerning practice 3.4 (We both compete and collaborate with our competitors), the reasons for this practice not being confirmed empirically as posited in the literature review are possibly twofold. Firstly, is that competing and collaborating with competitors is easier said than done. Whilst a progressive practice, it may still be perceived to be relatively foreign and perhaps threatening to the respondent organisations in this study. Secondly, it may be that this practice may not be familiar to all respondents at all levels in the organisations surveyed since not all of the respondents may necessarily be connected with directly competing organisations or be involved with projects where benchmarking is done.

\section{Literature Criterion 4: Customer centric, process- based, teaming organisation architecture}

The empirical confirmation of practices 4.1 to 4.4 of criterion 4 (e.g. Boxall \& Macky, 2009; Beer, 2009; De Toni \& Tonchia, 1994; Hunt, 2000; Joyce, 2005; Simon, 2000) was rated as High (see Table 8). These first four practices all relate to how a focus on the customer determines how the organisation thinks about and designs its business processes which constitutes the backbone of the organisation. Confirmation of practice 4.5 which relates to how and whether teams are built around business processes is rated as medium (see Table 8), suggesting that although confirmed empirically, this practice may not be as widely practised as the literature ventures to suggest.

Literature Criterion 5: Continuous improvement and relentless innovation

The empirical confirmation of practices 5.1, 5.2 and 5.4 of criterion 5 (e.g. Collins \& Porras, 2002; Joyce, 2005; Thorne \& Smith, 2002) is rated as medium (see Table 8), which suggests that although confirmed, the practices of innovative ideas evolving from working close to the customer and leaps of innovation being the norm rather than the exception may not be as extensively practiced as is put forward in the literature.

The empirical confirmations of the following practices are rated as low/not at all (see Table 8):

1. Practice 5.1: Good is never good enough. A relatively high standard deviation of 10.53 reported regarding this practice reveals that agreement on the criticality of this practice in business success is considerably varied. The disparity of responses to this practice suggests that although the literature reports that the practice of never being satisfied with the status quo is a world class practice, a wide divergence on the use of this practice exists in the study organisations. The reasons for this phenomenon may lie possibly with the way in which leadership questions the status quo, which results in spreading discontent and insecurity amongst their people for all the wrong reasons.

2. Practice 5.2: Competitive standards are achieved through benchmarking against other organisations. A likely reason for this practice not being confirmed empirically in this study is that benchmarking against competitors is easier said than done. Benchmarking against generally known industry measures is not uncommon but gaining access to and/or observing a competitor's practices by literally 'walking around with a clipboard' is another matter altogether. Besides this difficulty, benchmarking also requires that the organisation first undertakes a benchmarking study to do its internal homework as is outlined in the literature review. It may be that not all organisations are prepared to first do this 'homework' before setting off on a benchmarking excursion.

3. Practice 5.4: An inner urge for continuous improvement flows from what the organisation stands for. The reasons for this practice not being confirmed in the literature may be found in many of the respondents not being clear on the core ideology of their respective organisations. It would seem that whilst the literature reports that an inner urge for progress flows from what the organisation stands for, it assumes that all people in all world class organisations understand and have bought into the core ideology of their respective organisations. This is not always the case as can be seen from the results of this study.

Literature Criterion 6: An enabling and empowering people philosophy and practices are discussed, whereby the empirical

Confirmation of practices 6.1, 6.2, 6.4 and 6.5 of criterion 6 (e.g. Amaratunga \& Baldry, 2002; Beer, 2009; Gross \& Nalbatia, 
2002; Nel \& Beudeker, 2009; Veldsman, 2002) which relate to how people learn, are given feedback and are rewarded is rated as high (see Table 8). The empirical confirmation of practice 6.3 which relates to how multiskilled and multitasked people are flexibly deployed is rated as medium (see Table 8), suggesting that this practice is perhaps not as widely practised in the organisations surveyed as the literature would suggest.

\section{Literature Criterion 7: Powerful internal and external branding to build and support a strong organisation identity}

The empirical confirmation of practices 1.1 to 1.5 of criterion 7 (e.g. Calloway, 2003; Grulke \& Sibler, 2002; Swart, 2005) is rated as high (see Table 8). This is to be expected as branding is universally important.

In sum, whereas $85.7 \%$ of the practices in the study could be confirmed empirically relative to the literature reviewed as summarised in Table 8, there remains an implied assumption that all world class practices are applied consistently all the time by all organisations purported to be world class or which are ascending to becoming world class. This assumption has to be discussed next.

\section{The validity of world class criteria across developed and developing countries}

The untested assumption in the literature, 'one size of world class criteria fits all, irrespective of developed or developing country context' has to be rejected when physical location is used to classify organisations by country. It was found in the results reported in this study that there were combinations of criteria with their associated practices that are exclusive to developed and developing countries, four exploratory or confirmatory criteria (performance and reward driven people, ongoing stretch future driven strategizing, customercentric, shared vision-driven leadership and enabling and empowering people philosophy and practices) significantly differed between developed and developing countries. Three exploratory or confirmatory criteria (innovative, learning based partner-shipping, powerful branding and customer-centric business design) did not differentiate across countries. In all instances of difference, the extent of practice with respect to each criterion favoured developed country organisations. It appears that the criteria that are more people related are that ones that differentiate across countries. The more organisation related criteria do not differentiate.

The implication of this finding is twofold, firstly, combinations of criteria and their associated practices are country specific to developed or developing countries and secondly, that developed country organisations embrace world class criteria to a greater extent than their developing country counterparts. This finding provides an explanation why businesses in developed countries on the whole outperform their counterparts in developing countries. The practical significance of this implication has been built into the proposed empirically reconstituted world class model to be discussed later.

In terms of extent of practice by importance, the results revealed that the practices, leadership driving continual change, core capabilities that enable business processes are built through ongoing learning and innovative ideas born by working close to customers and suppliers are more important for developing countries. It can be argued that at a practice level, these three practices are more important in developing countries as a matter of necessity in a developing country context, rather than as ground breaking ways of doing business.

When physical location as a means of categorising organisations was excluded using cluster analysis, the participating organisations clustered into two groups, 'leading' world class organisations (the majority being in developed countries but also some in developing countries), where all of the exploratory criteria were favoured more and more extensively practiced in a developed than developing country context and 'trailing' organisations (the majority being developing country based, but some in developed countries). This finding implies that world class is not only an exclusive function of country context, although world class criteria were more closely associated with developed countries. In addition to physical location determining an organisation's world class status, world class must also be seen as an organic growth process that is governed by the choices made by the leadership to make their organisations world class or not regardless of location. Hence, the presence of world class organisations in developing countries and vice versa non-world class organisations in developed countries.

\section{Gaps closed in the existing knowledge regarding world class organisation}

The study closed three gaps in the existing knowledge regarding world class organisations. Firstly, it closed the gap in the understanding and application of world class criteria or practices between developed and developing countries. It was shown that the validity as indicated by the extent of use of these criteria vary across developing and developed countries. The implication of this finding is that world class criteria or practices have been contextually validated across developed and developing countries through a scientifically based study for the first time. These criteria cannot merely be assumed to be equally applicable across country types (see Beer, 2009 and Joyce, 2005 as good exemplars of this assumption). Secondly, along side physical location, the choice of an organisation's leadership to make their organisation world class or not, regardless of physical location is an important variable to consider. Thirdly, the study closed the gap in knowledge for organisations in developing countries, like South Africa, as to where its practices fall short of what is practised by leading world class organisations in developing countries. The implication of this finding is that it provides organisations in developing countries with a proposed empirically constituted model (see below) of world class together with recommended priority areas to ascend to world class.

\section{Proposed reconstituted model of world class organisations}

The literature review produced seven world class criteria with associated practices for each criterion. Factor analyses statistically regrouped the data, forcing a recreation of the original theoretical seven world class criteria into a reconstituted set of five exploratory and four confirmatory world class criteria with their respective practices as reported and discussed above.

Although the exploratory and confirmatory world class criteria did not apply equally to developed and developing countries, as it was shown, all these criteria and their associated practices are nevertheless performance-enhancing criteria. It is therefore proposed that all these criteria should be embraced across developed and developing countries from the perspective of leading and trailing organisations world class wise. It is for this reason that practices which are likely toenhance the performance of world class organisations in developing countries have also been highlighted in the empirically reconstituted, proposed world class model. A mind-map, encapsulating a proposed reconstituted world class model applicable to developed and developing countries, is graphically displayed in Figure 5.

The first level from the centre of the mind map portrays the reconstituted world class criteria, starting with customercentric, shared vision-driven leadership, as found in this study. Although the exploratory world class criteria are interdependent, the order in the mind map seeks to impose some sequence flowing in a clockwise direction, starting with the criterion customer-centric leadership, sharing their vision with all their stakeholders. Practices which are shaded are common to both developed and developing countries both in respect of extent of practice and importance to success. Criteria where 


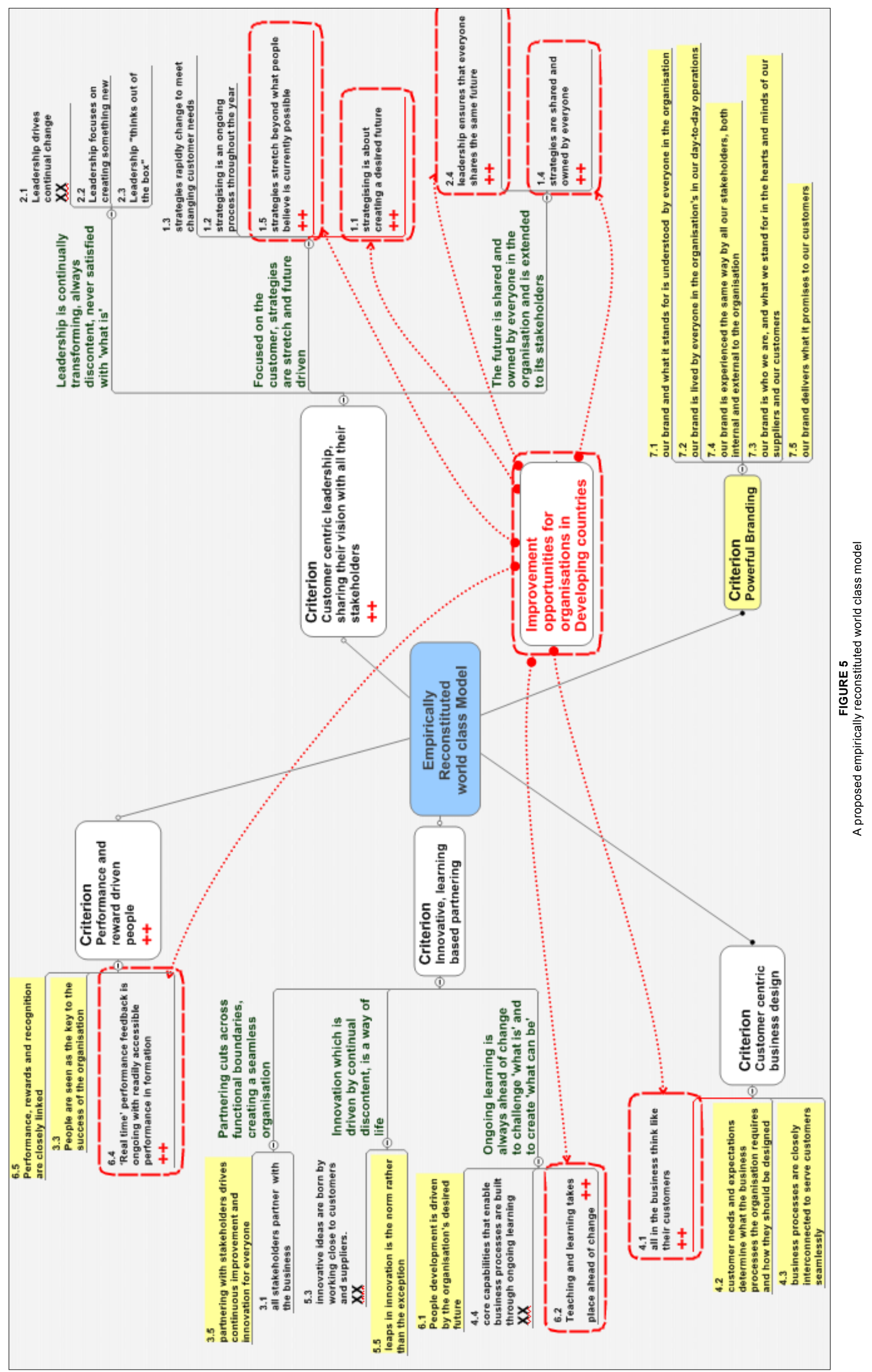


significant differences were found are introduced by way of $\mathbf{X X}$ (favouring developed countries) and ++ (favouring developing countries). The second level from the centre of the mind map contains descriptions which serve as subclassifications of some practices into subcriteria. Second level and where applicable third level, branches contain the original survey items (practices) from the literature review. Each practice carries its original numbering from the quantitative survey questionnaire as developed from the literature review.

The profile of world class organisations as per the seven literature-based world class criteria was constructed from a literature review. The key difference between the proposed empirically reconstituted world class model and the conceptual view from the literature is that the former provides for a practical sequential logic for how the world class 'story' unfolds. The latter provides for a theoretical model founded on a review of the literature. What follows is the profile of world class organisations empirically constructed from reconstituted world class criteria as mapped in Figure 5.

Transformational leadership which is centered on its customers, drives future-stretch strategies which rapidly change to meet the changing needs of their customers (Beer, 2009; Browne, 2003; Collins, 2001; Collins \& Porras, 2002; Joyce, 2005; Krames, 2005; Nel \& Beudeker, 2009, Veldsman, 2002). This 'future' is shared and owned by the majority in the organisation, and is also extended to all its stakeholders. World class leaders know that to win and keep the hearts and minds of their vacillating customers. They have to drive continual innovation and change to stay ahead of their competition (Beer, 2009; Flannery, Hofrichter \& Platten, 1996; Simon, 2000; Stewart, 2006; Van Dyk \& Herholdt, 2003). Driven by customer-centric leadership powerful branding is established to make it clear what world class is, what it stands for and what it promises to its customers. The brand promise resides in the hearts and minds of all its stakeholders. What the brand stands for is also experienced the same way by all their internal and external customers and stakeholders (Calloway, 2003; Grulke \& Sibler, 2002; Swart, 2005).

Thinking like their customers and fuelled by their brand promise, interconnected business processes are designed to service their customers. The organisation is designed around continually improving business processes in such a way that it can adapt to vacillating customer needs. Innovative ideas are born by working closely with customers and suppliers. This partnering cuts across functional boundaries to create a seamless organisation. Continual improvement is therefore a way of life (Boxall \& Macky, 2009; Beer, 2009; De Toni \& Tonchia 1994; Hunt, 2000; Joyce, 2005; Simon, 2000).

Ongoing process improvement and the change that it brings fuels the need for ongoing learning ahead of change to continuously challenge the status quo. People development is determined by a world class organisation's desired future. Real time performance feedback is ongoing with readily accessible performance information where performance, rewards and recognition are closely linked (Amaratunga \& Baldry, 2002; Beer, 2009; Gross \& Nalbatia, 2002; Nel \& Beudeker, 2009; Veldsman, 2002).

The question is whether there is any order in which the evolution to becoming world class should unfold? Three approaches are plausible, Firstly, that there is the sequence to be followed to becoming world class. The sequential order in which the exploratory criteria in the reconstituted world class model in Figure 5 have been described, starting clockwise with customer centric leadership sharing their vision with all their stakeholders, suggests a sequence to follow to ascend to world class. Secondly, that continuous incremental improvement over all world class criteria will systemically raise performance over time. Thirdly, is that there is a combination of both the first and second approach which embraces the Japanese yin and yang approach which rejects an 'Either/Or' in favour of an 'And' philosophy.

\section{CONCLUSION}

The implications of the reconstituted model of world class criteria and practices reveal that although the criteria and related practices in the model are sound, the extent to which the practices are applied on the ground are likely to differ between developed and developing country contexts because of empirically demonstrated differences in national cultures (Hofstede, 1980; Hofstede, 1991). Nevertheless, the study did reveal that there are practices which, if embraced to a much greater extent by organisations in developing countries, will positively impact their business performance. Adoption of a proposed empirically reconstituted world class model implies support for the view that becoming leading world class requires a deliberate leadership and organisation choice regardless of physical location. Thus physical location does play a role in being world class or not. But location has to be qualified by the choice exercised by leadership to be world class or not.

The study undertaken has the following strengths, firstly, a comprehensive literature review identified common views held by authors on world class practices whilst at the same time highlighting and bringing in some unique views that are not commonly reported on, secondly, opting for a quantitative approach, using a web-based on-line survey instrument enabled the researchers to reach targeted participants around the world within a tight time frame in order to compare organisations across developing and developed countries.

The study has the following weaknesses, firstly, the objective was to identify and then invite participating organisations which are considered world class in developed and developing country context. Whilst the initial objective was to survey an equal number of developing countries to that of developed countries, lack of cooperation from developing countries hampered this objective, relegating the research to southern Africa where sufficient participants could be found. Consequently, whilst reference is made to developed countries in the findings of the study, these findings are empirically more directly applicable to the southern Africa region than the rest of developed countries round the world. A more extensive sample involving other developing countries would have given more weight to the findings of the study. Secondly, the survey instrument was in English only and the researchers had to assume that respondents in non-English speaking countries would understand the content of the survey the same way. Although this could not be guaranteed, most senior executives across the world are assumed to have a reasonable command of English which would have negated much of the impact of language on the outcomes of the study. Triangulation of data by way of supplementing the quantitative data with qualitative data would have cast more light on why organisations in developing countries responded in the way they did. However, this would have required extensive resources and would have extended the time to complete the study to an unrealistic extent.

It is believed that future research in the area could entail the following, firstly, making comparisons between developing countries. Whilst the study sought to research the validity of world class criteria between developed and developing countries, the only countries where responses could be obtained were in the southern Africa region. Further research opportunities exist in establishing whether the empirically arrived at formula and those world class criteria applicable to a developing country like South Africa are equally applicable to developing countries in the rest of the world. Secondly, the reasons for phenomena arising from the results of this study are based on insights of and consequential suppositions by the researchers and have not been empirically researched for validity. For example, the reasons why organisations in developing countries like South Africa do not sufficiently share their strategies with their people are not clearly understood. A contextual supposition is the lower overall levels of work force education in South Africa. Further empirical research will uncover the real reasons whilst at the same time recommend appropriate interventions to close the gap. Thirdly, closing the gap between developed and developing countries caused 
by ever accelerating globalization. It is postulated that as globalisation shrinks the world even further, the differences in world class practices found between organisations in developed and developing countries will diminish rapidly. It is not known to what extent this gap has already closed or is progressing to close since this study only captures the differences between developed and developing countries at the time of this study. Fourthly, the practise of practices on-theground. Whilst some identified world class criteria differ and some are complementary between developed and developing country context, the on-the-ground practise of these practices (the way things are done) may reveal even greater differences. This will require on-site observation which may require triangulation of both qualitative and quantitative research. Fifthly, using organisation performance measures to validate criteria or practices and determining which criteria or practices are best predictors of success. Hard measures from one or more organisations in developed and developing countries respectively will validate the findings of this study and will also show which criteria are the best predictors of success and finally the determination of an evolutionary path to ascend to world class. Sixthly, the suggested evolutionary path to ascend to world class by way of the empirically reconstituted world class model requires validation in practice.

Ascending to world class is more than an imperative for survival in a rapidly consolidating global economy where only the fittest and the best will enjoy a place in the sun and thrive. Those which have proved themselves as the 'best in class' are showing the way to get to the top, irrespective of their country. It is now up to transformational thinking leadership to make the choice and take the necessary decisions to address the empirically researched opportunities provided in this study to become truly world class. Country context can no longer be used as a valid excuse for not getting to the top of the world class ladder. This involves an informed and deliberate leadership and organisation choice regardless of physical location.

\section{REFERENCES}

Amaratunga, D., \& Baldry, D. (2002). Moving from performance measurement to performance management. Facilities, 20 (5/6), 217-223.

Beatty, R.W., \& Schneier, C.E. (1997). New HR roles to impact organisational performance: from 'Partners' to 'Players'. Human Resources Management Journal (n.n),29-37.

Beer, M. (2009). High commitment, high performance. How to build a resilient organisation for sustained advantage. San Franciso: Jossey-Bass.

Boxall, P., \& Macky, K. (2009). Research and theory on high-performance work systems: Progressing the highinvolvement stream. Human Resource Management Journal, 19(1), 3-23.

Browne, R.F. (2003). CEO's Personal Revelation. Oklahoma City: The Great Plains Coca-Cola Company.

Budwar, P.S., \& Debrah, Y.A. (2001). 'Introduction'. In: P.S. Budwar \& Y.A. Debrah (Eds.), Human resource management in developing countries (pp. 1-16), London: Routledge.

Calloway, J. (2003). Becoming a Category of one. How Extraordinary companies transcend commodity and defy comparison. New Jersey: John Wiley and Sons.

Collins, J. (2001). Good to Great. New York: Harper Collins Publishers.

Collins, J.C., \& Porras, J.I. (2002). Built to last. Successful habits of visionary companies. New York:HarperCollins.

De Kock, P.M., \& Slabbert, J.A. (2003). Transformational leadership in business organisations ascending to worldclass status: a case study in the petrochemical industry. SA Journal for Industrial Psychology /SA Tydskrif vir Bedryfsielkunde, 29(1), 1-7.

De Toni, A., \& Tonchia, S. (1996). Lean Organisation, management by process and performance measurement. International Journal of Operations E Production Management, 16(2), 279.

Drennan, D., \& Pennington, S. (1999). Ladders to world class performance. London: Kogan Page Limited.
Flannery, P., Hofrichter, A., \& Platten, E. (1996). People, performance $\mathcal{E}$ pay. New York: The Free Press.

Gross, S.E., \& Nalbatian, H.R. (2002). Looking at rewards holistically. World at Work Journal. (2)52-55.

Grulke, W., \& Sibler, G. (2002). Lessons in radical innovation. London: Prentice Hall.

Hamel, G., \& Prahalad, C.K. (1989). Strategic intent. Harvard Business Review, 4, 63-67.

Hamel, G., \& Prahalad, C.K. (1994). Competing for the future. Harvard Business School, 8, 21-22.

Hofstede, G. (1980). Culture's consequences. International differences in work-related values. Beverly Hills: Sage.

Hofstede, G. (1991). Cultures and organizations. Software of the mind. London: McGraw-Hill.

Hunt, D.V. (2000). Process mapping. How to reengineer your business processes. New York: Wiley.

Japanese Standards Association (2003). TR Q 0005. Quality management system - Guidelines for sustainable growth, 5(E), 1.

Jones, C.R. (1994). Improving your key business processes. The TQM Magazine, 6(2), 25-29.

Joyce, W.F. (2005). What really works: Building the $4+2$ organisation. Organisational Dynamics, 34(2), 118-129.

Krames, J.A. (2005). Jack Welch and the 4 E's of leadership. How to put GE's leadership formula to work in your organisation. New York: McGraw-Hill.

Magee, D. (2003). Turn around. How Carlos Ghosn rescued Nissan. New York: Harper Collins Press.

Nel, J. (1994). Presentation to Coca-Cola Bottlers. Johannesburg: ABI.

Nel, C., \& Beudeker, N. (2009). (R)evolution. How to create a high performance organisation. Cape Town: Village of Leaders.

O'Neal, S. (1998). The phenomenon of total rewards. ACA Journal, 7(3), 6-22.

O'Reilly, C.A., \& Pfeffer, J. (2000). Hidden value. how great companies achieve extraordinary results with ordinary people. Boston: Harvard Business School Press.

Peters, T. (2003). Re-imagine. London: Dorling Kindersley Limited.

Pfau, B.N., \& Kay, I.T. (2002). The human capital edge: 21 People management practices your company must implement (or avoid) to maximize shareholder value. New Jersey: McGrawHill.

Rosenthal, R., Rosnow, R.L., \& Rubin, D.B. (2000). Contrasts and effect sizes in behavioural research: A correlational approach. Cambridge: Cambridge University Press.

Scheepers, J.M. (1992). Toetskonstruksie: Teorie en praktyk [Test construction: Theory and Practice]. Johannesburg: RAUdrukpers.

Simon, H. (1996). Hidden champions. Lessons from 500 of the world's best unknown companies. Boston: Harvard Business School Press.

Slabbert, J.A., Prinsloo, J.J., Swanepoel, B.J., \& Backer, W. (1998). Managing industrial relations in South Africa. Durban: Butterworth.

Slater, R. (1999). The GE Way Fieldbook. Jack Welch's battle plan for corporate revolution. New York: McGraw-Hill.

Stewart, T. (2006). Adapt or die in today's market. Business IT Africa, 6(3), 14-15.

Swart, A. (2005). Is your brand setting the trend? Business Day Management Review, 4, 1-3.

Telleria, K.M., Little, D., \& MacBryde, J. (2002). Managing process through teamwork. Business Process management Journal, 8(4) 338-350.

Thorne, K., \& Smith, M. (2000). Competitive advantage in world class organisations. Management Accounting Journal, 6(4), 21-22.

Tichy, N. (2002). The Leadership engine. How winning companies build leaders at every level. New York: Harper Collins.

Van Dyk, L., \& Heroldt, J. (2003). Transforming your employment brand. The ABSA Experience. Johannesburg: Knowledge Resources.

Veldsman, T.H. (2002). Into the people effectiveness arena. Navigating between chaos and order. Randburg: Knowledge Resources.

Zairi, M. (1994). Benchmarking: The best tool for measuring competitiveness. Benchmarking for quality management and technology, 1(1), 11-24. 